\title{
NARRATIVES AS SOURCES OF STABILITY AND CHANGE IN ORGANIZATIONS: APPROACHES AND DIRECTIONS FOR FUTURE RESEARCH
}

\author{
EERO VAARA \\ Aalto University School of Businesss \\ EM LYON Business School \\ Lancaster University \\ Management and Organization \\ Aalto University School of Business \\ PB 21230 \\ FI-00076 Aalto, Finland \\ +358 (0)503059359 \\ eero.vaara@aalto.fi \\ SCOTT SONENSHEIN \\ Jesse H. Jones Graduate School of Business \\ Rice University \\ scotts@rice.edu \\ DAVID BOJE \\ New Mexico State University \\ dboje@nmsu.edu
}

Accepted for publication in the Academy of Management Annals 
Narratives as Sources of Stability and Change in Organizations

\title{
NARRATIVES AS SOURCES OF STABILITY AND CHANGE IN ORGANIZATIONS: APPROACHES AND DIRECTIONS FOR FUTURE RESEARCH $^{1}$
}

\begin{abstract}
Although narrative analysis has made significant advances in organization and management studies, scholars have not yet unleashed its full potential. This review provides an understanding of key issues in organizational narrative analysis with a focus on the role of narratives in organizational stability and change. We start by elaborating on the characteristics of organizational narratives to provide a conceptual framework for organizational narrative analysis. We elaborate on three key approaches to narrative analysis on stability and change: realist, interpretative and poststructuralist approaches. We then review several topic areas where narrative analysis has so far offered the most promise: organizational change, identity, strategy, entrepreneurship and personal change. Finally, we identify important issues that warrant attention in future research, both theoretically and methodologically.
\end{abstract}

\footnotetext{
${ }^{1}$ We are grateful to Matthew Cronin and Laurie Weingart for the insightful comments and guidance throughout this process. We also wish to thank our colleagues at Aalto University School of Business, at the Jesse H. Jones Graduate School of Business at Rice University and at New Mexico State University as well as the many other scholars with whom we have been in touch for their help and suggestions that have greatly improved the paper. In particular, we want to acknowledge the help and comments of Charlotta Björk, Natalia Korchagina, Pikka-Maaria Laine, Anniina Rantakari, Stefanie Reissner and Paul Savage in putting it all together. We also want to express our gratitude to Grace Ann Rosile and 25 years of storytelling work done at the Standing Conference for Management and Organizational Inquiry (ScMoi http://scmoi.org).
} 
Narratives as Sources of Stability and Change in Organizations

\section{INTRODUCTION}

Narrative approaches play a key role in the humanities and social sciences (Bakhtin, 1981; Greimas, 1987; Propp, 1968; Ricœur, 1983). They have also become increasingly popular in management and organization studies, something that reflects both their utility and versatility. A large breadth of scholars covering a range of topics that span macro research such as strategy (Barry \& Elmes, 1997), meso research such as change (Boje, 1991, Brown, 2003; Sonenshein, 2010) and micro work such as personal growth (Maitlis, 2009; Sonenshein et al., 2013) have used aspects of narratives in their research. Some theorists also use narratology - the analysis of the structures, functions, themes, symbols, and conventions of narratives - to develop theories of organizations (Czarniawska, 2004; Boje, 2011).

In this paper, we seek to provide a critical review and guide to this potentially intimidating but also incredibly generative body of literature. We focus on the distinctive features of organizational narratives and aim at clarifying the relationship between multiple perspectives on organizational narratives across various topics areas. We define organizational narratives as temporal, discursive constructions that provide a means for individual, social and organizational sensemaking and sensegiving. While narrative analysis has typically focused on relatively coherent narratives that have a clear beginning and an end, we maintain that organizational narratives are often articulated only in fragments as a part of organizational discourses. Thus, organizational narrative analysis has to go beyond traditional forms of narrative analysis stemming from literary theory or linguistics (Boje, 2008; Bruner, 1986; Polkinghorne, 1988). We maintain that narratives are mobilized in various kinds of ways. This involves intentional storytelling 
(Boje, 2008), but narratives are also used and reproduced in many other ways as part of discourses and communication. Rather than focusing on narratives per se, we underscore their crucial role in stability and change in organizations (e.g., Dailey \& Browning, 2014; Frajoun, 2010; Feldman, 2000). That is, we argue that narratives provide an essential means for maintaining or reproducing stability and/or promoting or resisting change in and around organizations.

We start by offering an updated definition for organizational narratives that can serve as a conceptual basis for studying narratives in organizational contexts. We then elaborate on three approaches that researchers have used in organizational narrative analysis. We group the literature into realist approaches that focus on narrative representations and use narratives as data, interpretive approaches that concentrate on people’s constructions of organizational phenomena, and poststructuralist approaches which focus on deconstruction of dominant narrative representations and narrative emergence. All three streams have an important place in organization studies, but it is important to point to their inherent differences to advance organizational narrative analysis.

We then provide an overview of the role of narratives in stability and change in specific topic areas in management and organization research: organizational change, identity, strategy, entrepreneurship and personal change. We describe how each of these literatures has addressed key issues around stability and change. We finish by outlining an agenda for future research on narratives that highlights theoretical opportunities related to pluralism, reproduction, mobilization, resistance, dialogicality, inclusion/exclusion, and temporality. We also point to methodological issues that warrant 
attention in future research: transparency and reflection in the composition of narratives, the use of new forms of empirical material, and new tools of analysis and representation. In doing so, we encourage the wide range of perspectives in the literature that has allowed it to flourish. However, we also maintain a need to develop a common vernacular to help facilitate the development of narratives research. We offer several conceptual and methodological approaches to moving narratives research in organization studies forward along these lines.

In conclusion, the literature has been both blessed by and plagued with a variety of approaches to narratives research. Our ambition is to take the reader on a guided journey that elucidates the conceptual underpinnings of narratives and finishes with a preview of what a future might look like as scholars work in this exciting domain of research. Indeed, narrative research is a rapidly expanding literature in organization studies. Now is an ideal time to take stock of how the field has developed and outline a vision for its future.

\section{A BASIC CONCEPTUAL FRAMEWORK FOR ORGANIZATIONAL NARRATIVES}

Narrative research involves an interdisciplinary body of literature that spans across the social sciences and humanities. It has been applied in management and organization research in a variety of ways (for reviews, see Boje, 2008; Czarniawska, 2004; Gabriel, 2000; Rhodes \& Brown, 2005; Reissner \& Pagan, 2013; Rosile et al., 2013). For this reason, using a narrative perspective in organization studies often raises questions such as, “where do I start?” and “which approach do I use?” The epistemological and methodological pluralism provides for a rich body of research but also comes with critical challenges. On the one hand, we need to have a clear overall understanding what 
organizational narratives are. On the other, there is a need to develop comprehension of specific approaches to narratives with their fundamentally different onto-epistemological assumptions and methodological preferences. We will start with the overall definition in this section followed by detailing three distinctive approaches to narratives in the next section.

Organizational narratives have at least six key features. First, organizational narratives are temporal, discursive constructions that provide a means for individual, social and organizational sensemaking and sensegiving. They are thus often associated with other language-based perspectives such as organizational discourse (Phillips \& Oswick, 2012), rhetoric (Cheney et al., 2004), framing (Cornelissen \& Werner, 2014) or vocabularies (Lowenstein, Ocasio \& Jones, 2012) without addressing what makes narratives a unique form of discourse. We maintain that it is the temporal aspect of narratives that distinguishes them from other forms of discourse, and that this temporality provides a key way of understanding issues such as stability and change in organizations.

Second, organizational narratives are not often fully-fledged stories or accounts as classical narrative research in literary theory or linguistics assume (Boje, 1991, 2008). The temporal plotlines are not always explicit and can remain implicit in organizational narratives. This is party due to the fact that organizational communication is often complex, ambiguous and fluid. Another reason is that because of their knowledge, people in around organizations often only need to be prompted by some key words to develop narratives understanding. Thus, narrative analysis in management and organization studies must also comprise fragmented narratives where elements of narrative structures such as the end or the beginning are implicit. Moreover, organizational communication 
also involves ideas that have not yet become widely shared. These can be conceptualized as 'proto-narratives' or 'antenarratives' that are elementary forms of narratives that may or may not develop into fully developed storylines (Boje, 2008).

Third, a narrative view requires a focus on the means by which they are produced and consumed. The terms narrative, account, and story are often used interchangeably. To be clear, we understand stories as existing narratives that can be told and retold in various forms. Accounts are people's own narrative descriptions of organizational processes, events and phenomena. Narration and storytelling are also key terms in narrative analysis. Narration is the process in which narratives are told, whereas storytelling is the activity that spreads various kinds of stories in and around organizations (Boje, 2008, 2014). However, we maintain that organizational narratives are often spread without particular intentionality or deliberate action.

Fourth, although we focus on organizational narratives, we emphasize that they are parts of multifaceted structures. At the macro level, researchers have linked organizational narratives with broader societal narratives that reproduce dominant values and ideologies (Lyotard, 1979). Thus, it is important to contextualize organizational narratives to be able to understand their role in stability and change. At the micro level, organizational narratives are composed of discursive and rhetorical elements. These elements are in turn important to understand the spread or appeal of specific narratives.

Fifth, while narratives in management and organization studies are usually associated with language (written or spoken), we maintain that they can also include and relate to other forms of communication and modes (especially visual and audio). This is one of the key challenges that we will come back to in more detail in the future directions 
part of the paper.

Sixth, narratives play a key function in terms of stability and change in organizations. At one level, people’s accounts or researchers’ narratives provide descriptions of sequences of events, which frame these events as change or stability. At another level, organizational narratives can also be influential in organizational processes, thereby changing the trajectory of events that unfold, which in turn may change the organization or reproduce the status quo. In this regard, narratives have performative power (i.e., narratives are constitutive acts) and agency (i.e., narratives may bring about change in organizations).

\section{NARRATIVE APPROACHES TO STABILITY AND CHANGE}

We now present and elaborate on three distinctive approaches to organizational narratives: realist, interpretative and poststructuralist approaches. Their main features are summarized in Table 1. Although we wish to highlight the distinctive nature and differences of these approaches, studies sometimes combine elements of different approaches.

Insert Table 1 around here

\section{Realist Approaches: Narratives as Representations or Data}

In realist perspectives, narratives are means to study things that exist independently of the narratives themselves. These approaches resonate with realist or positivist understandings of organizational phenomena where narratives per se are not in the focus of the analysis but are seen as representations of other phenomena. In the following, we highlight two distinctive types of realist approaches to narratives: narratives as representations or interpretations of cases, and narratives as data to be used to explain or understand other 
phenomena.

Narrative representations. A first approach focuses on the researcher's construction of the case at hand, and the term narrative alongside similar ones such as 'tale' are used to describe the researcher's construction of the case. One of the most popular uses of this form of narrative occurs in process studies that play a central role in understanding stability and change (Pentland, 1999; Van de Ven and Huber, 1990). For instance, Van de Ven and Huber (1990) consider narratives as key parts of longitudinal research, and Langley (1999) has focused attention on different types of researcher's narratives of organizational processes. Like many historians, Burgelman (2011) has explained how longitudinal case studies combine an historical narrative understanding of a case leading to particular generalization with the reductionism of social science aiming at general particularism. Van Maanen (1988) has in turn elaborated on the types of ethnographic tales or narratives that researchers may produce, and distinguished between realist, confessional and impressionist tales where the realist tales are the objective descriptions of events, while the confessional and impressionist tales describe the researchers' own experiences with personal or selective examples. We are not focusing on the researcher's narratives in this review, but want to emphasize that they are always a key part of the analysis of stability or change, which is in issue that we will come back to in the section on methodological challenges.

Narratives as data. Narratives have frequently been used as sources of data to access phenomena that exist independently of the narratives in question. This type of narrative analysis thus follows 'normal science' where narratives are an important source of information among others. The range of these studies varies from the casual use of the 
term narrative to refer to interview data to using narratives as a basis of capturing experiences or socio-psychological processes. Thus, organization scholars have drawn from different sources, including structured positivist methods to use narrative data (e.g., Abbott, 1992) or selective application of the methods of 'narrative inquiry’ originating from the work of Polkinghorne (1988), among others. In the following, we will provide examples of a variety ways in which realist narrative analyses can be conducted.

An early example is provided by Stevenson and Greenberg (1998) who used narrative interview data as part of an event-structure analysis (Griffin, 1993) to examine how organizational mobilization led to change in a policy for the use of parks in a small city near Boston. They first constructed an overall understanding of events based on narrative data. Then they analyzed the key events to distill an event-structure with causal relationships between events and actions. This involved the following steps: auditing (external view on the initial interpretations), insider-outsider perspectives, multiple data sources, identifying important events, counterfactual arguments, and revisiting the data. After iterations, this led to a convergent mapping of the key turning points in their reconstruction of the events (their own researcher's narrative that was based on the informants' narratives). As a result, they could show that organizational mobilization tends to be less coordinated and more affected by environmental pressures than researchers typically think.

More recent studies have frequently used narratives as a critical component to explain some type of change relevant outcome. For example, Sonenshein (2006) examined issue crafting, i.e., how individuals shape the meaning of issues by language use, by using narratives as data. He captured change agents’ narratives to influence others 
about a change by having working professionals write a memo to either a boss, direct report or co-worker. He compared these public narratives with a private narrative subjects had written beforehand. In comparing the two narrative types, he found that the public narrative contained a higher frequency of economic and lower frequency of moral language. Thus, narrative analysis helped to understand how people crafted issues in public versus private spheres. In another study, Sonenshein and Dholakia (2012) gathered employees' narratives of organizational change, and then related these narratives to change behaviors which were mediated by psychological resources. They found that two themes in employees' narratives—strategy worldview and benefits finding — served as psychological resources that led to more engagement with a strategic change.

Martin (In Press) in turn examined how narratives can advance organizational values in a field experiment of newly hired employees at a large IT firm. They found that stories from lower level employees upholding values are more positively associated with helping behaviors and negatively associated with deviant behaviors, compared to similar stories from those higher up in the organization. Furthermore, their study showed that when high-level protagonists are featured in value-violating stories, they have the strongest effect on suppressing helping behaviors. This study suggests that stories convey values differently, depending on their protagonist.

Yet another illuminating example is provided by Martens, Jennings and Jennings (2007) who examined how storytelling impacts a firm’s ability to secure capital. They argued that narratives help to establish a comprehensible identity for a firm, to elaborate the logic of entrepreneurial opportunities, and to embed the firm's activities in broader discourses. Their statistical analysis found support for the hypothesized positive effects. 
Narratives as Sources of Stability and Change in Organizations

Thus, the study revealed how storytelling impacted performance in a positive manner. Herzenstein et al. (2011) picked up on similar themes, analyzing the identity claims embedded in narratives to influence acquiring loans using crowdfunding. These studies thus illustrate how realist narrative analysis may be combined with statistical analysis to examine their organizational effects.

\section{Interpretative Approaches: Narrative Constructions as Objects of Study}

In interpretative approaches, narratives are conceptualized as people’s constructions of organizational phenomena. Interpretative approaches have played a central role of organizational narrative analysis as it has developed into a distinctive research area (Czarniawska, 1997, 2004; Gabriel, 2000). Interpretative narrative analyses tend to draw from literary studies such as Greimasian structural analysis of narratives (Greimas, 1987) or social psychology such as Bruner's (1986) work the central role of narratives in social cognition. In organization and management studies, they have frequently been linked with sensemaking as an overall theoretical frame and come in two primary forms we review below: individual narratives and composite narratives.

Individual narratives. Some studies focus on individual accounts or stories and analyze them with narrative methods (Gertsen \& Søderberg, 2011; Pedersen, 2009). Such studies have often drawn from classical narrative frameworks and methods (e.g., Greimas, 1987) to analyze accounts or texts from a narrative perspective. For instance, Gertsen and Søderberg (2011) have analyzed stories of collaboration in a multinational corporation. In their analysis, they focused on two narratives: one of a Danish expatriate manager and another of his Chinese CEO in Shanghai. Their analysis was based on Greimas’s (1987) actantial model that allowed them to elaborate on specific turning points and the 
constructed roles of the key actors in these stories and compare them. This led to a mapping differences between and changes in the narrators’ projects, alliances and oppositions in the course of their interaction. This analysis in particular helped to understand how they overcome their differences and established common ground.

Pedersen (2009) provides another kind of example where she focuses on the role of space and time in narratives that deal with change in a hospital context. In her analysis, she unravels a consultant's, a social worker's and a senior nurse's stories with a Bakhtininspired focus on chronotopes, i.e., space-time configurations in the narratives. In this analysis, she also makes use of Morson’s (1994) ideas about side- and foreshadows as alternative scenarios to the main plots. Sideshadows are alternative versions of how events could unfold, and foreshadows represent constructions of the future. She elaborates on each of the three stories and then discusses their differences.

Composite narratives. The bulk of interpretive research, has focused on interpretative patterns (Polkinghorne, 1988) to build composite narratives that capture the collective meanings of a group of organizational members. Researchers typically put together these composite narratives by collecting narratives from several organizational actors (Dunford \& Jones, 2000; Currie \& Brown, 2003; Balogun \& Johnson, 2004). For example, Currie and Brown (2003) conducted a case study at a hospital and created a narrative not articulated by any one informant but rather formed from fragments from many. This provides the opportunity for scholars to identify and represent patterns in the narratives of groups of organizational actors and to compare those with others. This comparison between different narratives then allows one to examine polyphony or plurivocality, i.e. different interpretations of stability and change across narratives, as well as their 
implications.

Sköldberg (1994) provides an early example of such an approach. Based on an analysis of organizational change in Swedish local government organizations, he focused on how the people involved experienced the changes as expressed in their narrative accounts. His analysis showed how people in each of the units could tell different kinds of narratives. This led him to identify and elaborate on three types of narrative genres: tragedy, romantic comedy and satire. On this basis, he argued that narrative conventions and their genres, rather than more substantial concerns, formed the meaning of the changes for the people involved.

Vaara (2002) offers another kind of example of interpretative analysis in his study of success and failure in post-merger organizational change processes. By combining ideas from critical discourse analysis and Greimasian narrative analysis, he distinguished between four types of narrative discourses: rationalistic, cultural, role-bound, and individualistic. These discourses provided different kinds of means for the managers involved to make sense of success/failure, to attribute credit and blame, and to account for their own responsibility.

Another illuminating study is provided by Sonenshein (2010) who examined the narrative construction of organizational change processes. His analysis drew from Gergen and Gergen’s (1997) ideas about different types of narratives and insights from sensemaking research to elaborate on the ways in which the people involved interpreted and responded to strategic change. Based on a number of interviews and other empirical material, he identified progressive, stability and regressive narratives that each provided different means for making sense of and giving sense to the changes. Progressive 
narratives link experiences or events towards a good evaluative dimension, such as about how the organization will improve. Regressive narratives connect experiences or events towards a bad evaluative dimension, such as a resistance to change narrative. Stability narratives keep the evaluative dimension the same, thereby allowing familiar meanings to comfort organizational actors. All three narratives interact to create understanding of stability and change.

\section{Poststructuralist Approaches: Narrative Deconstruction and Narrative Emergence}

Narrative analysis has also drawn from poststructuralism, often including critical perspectives. We adopt a broad view on poststructuralism here as a number of poststructuralist influences can be found in streams of narrative organization studies (e.g., Boje, 2014). While interpretative studies focus on the description and elaboration on narratives that play a central role in the social construction of organizational reality, poststructuralist studies aim at uncovering the complexity, fragmentation and fluidity of narrative representations. We highlight two kinds of poststructuralist studies: narrative deconstruction that aims to problematize prevailing or dominant narratives, and narrative emergence that seeks to uncover the central role of emerging narratives in organizational processes.

Narrative deconstruction. Critically-oriented poststructuralist narrative analysis often problematize the ways in which prevailing or dominant narratives represent things and point to specific assumptions that underlie these narratives (Boje 1995; Buchanan 2003; Buchanan \& Dawson 2007; Collins \& Rainwater 2005; Martin, 1990). Moreover, these analysis often focus on the problems of narrative hegemony, i.e., privileging some narratives over others, and attempt to reveal marginalized voices (Beech, MacPhail \& 
Coupland, 2009; Brown, Humphreys \& Gurney 2005; Cunliffe et al., 2004).

An early empirical example of such studies is provided by Boje (1995) whose postmodern analysis of Disney focused on storytelling and the various narrative discourses used to describe the corporation's history. The purpose of the analysis was to reveal the marginalized voices and excluded stories of a 'darker side' of the Disney legend. In particular, the analysis contrasted Disney's official Walt-centered narrative with alternative representations and voices. This led Boje (1995) to suggest that organizational storytelling may be characterized by totalisms (hegemonic representations), universalisms (universal generalizations) and essentialisms (objectification of experiences) that easily pass unnoticed in more conventional analysis. He also proposed that Tamara, a play where one can develop alternative storylines, can be used to refer to analysis that seeks to identify different narratives and counternarratives instead of focusing on dominant or hegemonic ones.

Some studies have more explicitly deconstructed and critiqued particular narrative representation. For instance, Collins and Rainwater (2005) offer a critical analysis of a widespread account of Sears's corporate transformation. They examined bottom-up stories of change and highlighted the complexities and polyphony in them. They focused special attention on ideas and voices that were "edited out" of the dominant narrative. Analogically, for example, Buchanan and Dawson (2007) have elaborated on the problems of monological, i.e., single-voice and one-sided, research accounts that stifle multiple interpretations and plurivocality. Thus, they have called for an approach that views organizational change as a multi-authored process.

Others have then examined what dominant or monological narratives imply for 
the individuals involved (Beech et al., 2009; Driver, 2009). Some of these studies have focused on the performativity of narratives, which refers to how specific storylines are repeated and performed with specific implications on people. For example, Driver (2009) drew on Lacanian psychoanalytic theorizing to examine narratives of loss in organizational change. In this view, normal discourse or narrative in and through which people construct the self is an imaginary construction or a fantasy for the person in question. This fantasy tends to create a stable identity for the self and 'fix' one's desires. In her analysis of 40 stories, she promoted the poststructuralist argument that it is not organizational change that makes organizations, work and self lacking, but that it may be change that brings to the surface the lack that is always there. On this basis, she called for alternative types of stories and narratives to highlight the complexities and ambiguities involved and to empower the people confronted with losses.

Narrative emergence. Relatedly, studies with a poststructuralist orientation have also examined how narratives and stories emerge and come to play a central role in the social construction of organizational phenomena and thus stability and change. Accordingly, narratives are an essential means of becoming in organizations (Chia, 1999), which resonates with an understanding of organizations as continuously reconstructed entities (Tsoukas \& Chia 2002). This view has often been called 'ontological' as it underlines that narratives socially construct organizations and organizational phenomena, and accordingly it is of special interest to study how certain narratives and not others formed the basis of widely shared understandings (Boje, 2008, 2014). The concept of 'antenarrative' - a form of narrative that has not yet become widely shared but has the potential to become one (Boje, 2008, 2011) - is useful because it allows one to better 
understand and examine how specific narratives emerge out of the flux of a number of alternative discourses.

Boje, Rosile, Durant and Luhman (2004) offer an illuminating example of antenarrative analysis in their study of the Enron scandal. They focused on the antenarrative fragments of marginalized and backgrounded stories. They analyzed these antenarratives as part of the mediatized crisis where specific antenarrative ideas and practices resonated with particular actors and audiences. They especially pointed out that corporate power seemed to be linked with the logic of heroic storytelling and resistance linked with the logic of carnival. All this had a major impact on Enron and the way that its scandal unfolded.

In another paper, Vaara and Tienari (2011) use antenarrative analysis to examine change in an international merger case. They focus on how antenarratives are mobilized as discursive resource to promote or resist change. They distinguished between three types of antenarrative that provided alternative ways for making sense of merger: globalist, nationalist and Nordic antenarratives. They then analyzed how these antenarratives were mobilized by organizational actors as the merger process unfolded. Following Boje (2008), they elaborated on four types of dialogisms in this mobilization of the antenarratives: polyphony in terms of multiple voices, stylistic dialogisms in various modes of representation, chronotopes as space-time configurations, and architectonic dialogisms in the form of interplay of various cognitive, aesthetic and ethical discourses.

Finally, such analysis of emergence may also deal with embodied narratives and storytelling. In a rare example, Cunliffe \& Coupland (2011) offer an embodied narrative 
sensemaking perspective. Their analysis focused on the lived experience of the 2001 British and Irish Lions rugby tour of Australia. They argue that people make sense of their lives in embodied interpretations and interactions with others. In their model, this occurs in and through a number of alternative and often contested narrative performances where people try to construct sensible and plausible accounts that are responsive to the moment and to retrospective and anticipatory narratives.

In conclusion, the three main approaches provide very different kinds of bases for narrative analysis of organizational stability and change, and they also offer a means to focus attention on specific research questions. The realist approaches deal with longitudinal representations of stability and change and examine the effects of narratives on other phenomena. Interpretative studies examine the construction of narratives and focus on issues such as polyphony, providing an important window into the multiple meanings of stability and change and their implications for the people involved. Postrustructuralist narrative studies criticize hegemonic presentations, uncover marginalized perspectives, or examine organizational emergence and becoming. These approaches help to advance our understanding of the dynamics of stability and change in distinctive but complementary ways, and we now turn to how they have been applied across specific topic areas.

\section{THE ROLE OF NARRATIVES IN STABILITY AND CHANGE IN KEY AREAS}

Drawing on the three approaches to narrative analysis, management and organization scholars have applied narrative analysis to various topics (for reviews, see Czarniawska, 2004; Rhodes \& Brown, 2005; Rosile et al., 2013). In this section, we provide an overview of the role of narrative analysis in organizational change, identity, strategy, 
entrepreneurship and personal change as these vibrant research areas can illuminate the potential of narrative analysis. Our overview is, however, not exhaustive since narrative perspectives have also been used to examine other themes such as knowledge (Boland \& Tenkasi, 1995; Patriotta, 2003), innovation (Bartel \& Garud, 2009), learning (Garud, Dunbar \& Gartel, 2011; Morris \& Moore, 2000; Oswick et al., 2000), standardization (Haack, Schoeneborn \& Wickert, 2012), memory (Adorisio, 2014), and gender studies (Phillips, Pullen \& Rhodes, 2014),

\section{Narrative and Organizational Change}

Various kinds of narrative perspectives have been prominent in research on organizational change. This is not surprising given that change almost necessarily involves a narrative representation because of its temporal development. As devices to capture, interpret, construct and change organizational time, narratives help scholars to understand how organizations evolve and how actors shape this evolution.

Illustrative studies. Narrative analyses of organizational change have concentrated on themes such as the meaning of change, plurivocality or polyphony (i.e., multiple interpretations), and the implications of narratives and storytelling on the change process itself (see Table 2 below).

Insert Table 2 around here

Scholars have dug into the meanings of change by interpreting their deep structure in narratives. As noted above, Sköldberg (1994) viewed organizational change as unfolding dramas that include genres such as tragedy, romantic comedy and satire. Thus, organizational actors weave symbols of organizational change to create accounts of what happens and why. Relatedly, Carlsen (2006) drew on narrative psychology to explain 
organizational change as a "becoming" process driven by instantiating project experiences as identity exemplars, dramatizing trajectories of practice, and reframing.

Given the complexity of change, it is a single narrative rarely captures the expansive nature of change, and hence research on organizational change has focused on plurivocality or polyphony. In an early narrative analysis of change, Boje (1991) examined storytelling and its impacts on change in everyday conversations. A key finding was that instead of remaining the same, the stories were dynamic and varied by context. As noted above, Sonenshein (2010) finds that narratives of organizational change differ by the extent to which they construct organizational life as progressive, regressive or stable. Reissner (2011) has in turn distinguished between stories of "the good old days,” deception, taboo and silence, and influence.

By emphasizing the plurivocal or polyphonic aspects of narratives, organizational change narratives can reveal alternative meanings that impact change that may otherwise go unnoticed. In their poststructural analysis, Fronda and Moriceau (2008) examined the change processes during a takeover of a telecommunications company. By analyzing the often-concealed narratives of employees, scholars can thus understand resistance not as a blanket rejection of a change but rather as search for meaning and a desire to understand the purpose of change (Ford, Ford, \& D’Amelio, 2008; Sonenshein, 2010).

Given the ambiguity during change, narratives can label organizational events in important ways. Different narratives, advanced by varying constituents with their own interests, can portray and shape others' interpretations of the events unfolding around them. In other words, narratives have tremendous power as an organizational scorekeeper. Along these lines, Vaara (2002) examines how narratives socially construct 
the success or failure of change initiatives. Other scholars have emphasized how narratives keep score of morality during organizational change. Issues around who is narrating and how they shape change processes raise questions of fairness, representation and morality. Sonenshein (2009) examined how narratives ascribe different types of ethics to the same change process, with managers tending to narrate organizational events in strategic terms that conceal morality, and employees emphasizing an employee welfare frame that brings issues of ethics to the foreground. Rhodes, Pullen and Clegg (2010) in turn studied narratives at a technology company and found the telling of "the inevitable fall from grace” such that the once prosperous organization was destined to decline and downsize. This narrative portrayed the organization as a victim rather than an active agent morally responsible for its actions.

Finally, researchers have also elaborated on the agentic role of narratives in organizational change. Buchanan and Dawson (2007) argue that narratives can have causal impacts on organizational change by shaping understandings of the past and trajectories of the future. Not only do actors compete to establish a dominant narrative about change, but these dominant narratives can also alter the trajectory of the organization in the future. This is particularly likely given that when organizational actors retell narratives, their primary focus is usually not on accuracy but plausibility and some kind of coherence. Indeed, Dailey and Browning (2014) emphasize that it is narrative repetition in and of itself that promotes change and/or then stabilizes particular meanings. Consequently, narratives shape how organizational actors understand the organization and reconstitute it through their discourse and actions.

Contribution to stability and change. This stream of narrative research has helped us to 
better understand the meaning of organizational change for the actors involved, and thus advanced research on organizational change more generally. In particular, these studies have highlighted how differently individuals or groups may imbue organizational change with different meanings (plurivocality or polyphony). Furthermore, narrative analyses of organizational change have shown how the narratives themselves or organizational storytelling may have significant implications for promoting change or maintaining stability.

Untapped research questions. Although we know a great deal of organizational change, a narrative perspective affords the opportunity to address issues and questions other approach have left unresolved. For instance, given that temporality plays such a pivotal role during change, a narrative perspective's emphasis on temporality affords the opportunity to investigate how organizational actors subjectively experience time to make meaning of unfolding change (Cunliffe, Luhman \& Boje, 2004). Similarly, a closer analysis of polyphony and its forms in change (Belova, King \& Sliwa, 2008) could help to better understand how interpretations of change diverge or converge in unfolding change processes and the implications. Finally, it would be interesting to know more about the rhetorical means that may determine whether storytelling is influential in promoting organizational change or undermining its success. It would among other things provide insights into the role of storytellers and their credibility and power in the organization context.

\section{Narratives and Identity}

Narratives have played a prominent role in research on personal, work, professional, organizational, and national identities. This is easy to understand given the proliferation 
of research linking identity and identification with narratives in various streams of social sciences (Bruner 1986, 1990; Polkinghorne, 1988; Ricoeur 1983). Furthermore, landmark studies of organizational culture and identity have from the start emphasized the role of stories or narratives (Martin, Feldman, Hatch \& Sitkin, 1983).

Illustrative studies. Narrative analyses have focused on identity-building at individual, organizational and national levels of analysis and examined related dynamics of identity building (see Table 3 below).

Insert Table 3 around here Narrative research has examined identity-building at the individual level. Ibarra and Barbulescu (2010) elaborate on the narrative forms of expressing and claiming identity. They develop a theoretical model of narrative identity work that elaborates on the role of authenticity (construction of the self) and validation (perceiving the narrative as credible) in such storying. This leads them to emphasize coherence, legitimation and audience reaction in these narratives. Whittle, Mueller and Mangan (2009) studied the role of stories in the construction of actors' moral status and organizational reputation. Their analysis concentrates on the development of a key actor whose identity shifted from that of an innocent victim to a villain to a heroic survivor in the stories constructed during routine work conversations. Thus, the nature of 'moral accounting' varied depending on the need to save face in the interactional situation. Gabriel, Gray and Goregaokar (2010) examined stories of managers facing unemployment. Their analysis identifies three narrative coping strategies that unemployed managers used to make sense of the dismissal and to sustain their self-identity. Those who were the most severely hit seemed to reach closure in their narratives whereas those who maintained a more positive outlook 
for the future appeared to produce more open-ended narratives. In another context, Wright, Nyberg and Grant (2012) examined how individuals deal with controversial issues such as climate change. They demonstrated how individuals seek to overcome conflicts between identities in constructing a coherent narrative of themselves and their careers. Koerner (2014) has in turn focused on identity and workplace courage. Her study distinguishes between four distinct forms of courage and one storyline that reflects a lack of courage.

Narrative analyses have also focused on the linkage of individual and organizational identities (Brown, 2006). Fiol (2002) theorizes that narratives both reflect and produce processes of identification in discourse. In adopting a Lewin-inspired framework of unfreeze-move-refreeze, she theorizes that narratives help employees bridge change and stability by providing them with language to dis-identify with the old and re-identify with the new. Similarly, Humphreys and Brown (2002) studied organizational identification and showed how it may be related to different forms of resistance. In addition to embracing widely spread organizational identities, the narratives could involve neutral, dis-, schizo-identification. Neutral identification means a distanced linkage between the self-identity and that of the organizational identity narrative. Disidentification describes an active and negative connection between the self-identity and that of the organization. Schizo-identification means simultaneous identification and disidentification with the organizational narratives. As noted above, Cunliffe and Coupland (2011) demonstrate how a sense of identity as part of a collective is developed through a myriad of interactions of embodied narrative sensemaking.

Narratives specifically provide means to construct and reconstruct the identity, 
image and purpose of an organization (Chreim, 2007). An early example is Boje’s (1995) analysis of Disney that contrasts the dominant widespread identity narrative with other interpretations. As noted above, this analysis helps to understand the implications of some narratives becoming dominant while other interpretations are stifled. Chreim (2005) examined how narratives of organizational identity enable an organization to manage continuity and change by selectively telling aspects of an organization's past, present and future. She focuses on how organizations also use expansive labels that allow for the addition and subtraction of meanings to confirm identity changes advanced by senior managers, even while media accounts provide alternative interpretations. Maguire and Phillips (2008) use narratives to examine how institutional trust at Citigroup becomes undermined because of ambiguity in the firm's identity after a merger, and later becomes undermined by the lack of employee identification with the new organization. This study suggests the importance of narratives in providing a viable identity that resonates with employees.

Other studies have elaborated on the means through which new organizational identities are legitimated. Ybema (2010) examined how organizational actors at a Dutch newspaper recasted their identities by contrasting the old with the new. Wry, Lounsbury and Glynn (2011) in turn focus on how nascent collective identities are legitimated. They argue that legitimacy is more likely to be achieved when members share and spread a collective identity story. Similarly, Schultz and Hernes (2013) provide a temporal perspective on organizational identity in which constructions of the past, present and future play a crucial role. Their case study of LEGO provides examples of two occasions where the past was evoked distinctively differently to influence claims for future identity. 
Thus, these studies point to the various narrative and rhetorical means to promote specific organizational identities.

Finally, some studies have focused on national and international identities. As mentioned above, Gertsen and Søderberg (2011) have shown how narrative methods provide useful tools to understand identity construction in international settings. They focus on two stories told about the cooperation between a Danish and a Chinese manager and highlight how the plots and turning points differed and allow one to better understand cultural differences and identification in MNCs. As noted above, Vaara and Tienari (2011) examined how managers and the media mobilized antenarratives to construct national, inter-national and global identities in a merging banking group. These identity constructions proved to be crucial in legitimating change.

Contribution to stability and change. This stream of narrative research has highlighted identity-building dynamics at individual, organizational and international levels of analysis. These studies have shown how narratives are an essential means to maintain identities, reshape existing identities, or to build new ones. They also demonstrate how these narratives constantly reconstruct understandings of the past, present and future, including opportunities for revision and resistance.

Untapped research questions. Although we now know a great deal about the central role of narratives in identity-building, recent studies indicate that there is much more to be studied to better understand the complexities, ambiguities and contradictions in identity narratives. Of special interest is the relationship between individual and organizational identity narratives as they inform us about people's identification with organizations and their reactions to change, including resistance. It would also be 
important to examine in more detail the rhetorical and discursive means through which particular organizational identities are constructed and legitimated. Not only verbal or written texts, but also visual representations and material artefacts are likely to play an important role in these processes, and their analysis remains a key challenge for future research. This is especially relevant in light of the proliferation of narratives about organizations outside of the focal organization, such as on the Internet and in social media networks.

\section{Narratives and Strategy}

Strategy research offers an important area for our review because of its growing body of narrative studies. This is especially the case with strategy process and practice studies as well as research on strategic change.

Illustrative studies. Most of this research has been theoretical in orientation, with a surprisingly few number of studies providing empirical perspectives (see Table 4 below). Key themes in this body of work include the narrative construction of organizational strategies, the role of narratives in strategy work, and the role of storytelling in strategic change.

\section{Insert Table 4 around here}

Scholars have focused attention on the narrative construction of organizational strategies and specifically conceptualized strategies as future-oriented narrative constructions. In a landmark theoretical paper, Barry and Elmes (1997) provocatively put forth a view on strategic management as fiction and more specifically conceptualized strategy as a form of narrative. Drawing on the narrative theory of Shklovsky, they agued that as narratives strategies must be credible (or believable) and defamiliarizing (or novel) and that there is 
often a tension between these two aims. They also distinguished between specific genres of strategy narrative: epic (dramatic, heroic tales), technofuturist (complex and detailed 'quasi-scientific' texts) and purist (defamiliarizing, almost atemporal stories) genres. Drawing on Bakhtin's and Boje’s (2008) work, Vaara and Pedersen (2014) have used the concept of 'chronotope' (the configuration of time and space in narratives) to elucidate the temporal aspects of strategy narratives. They argue that specific chronotopes characterize particular literary genres, which each can serve as bases for different strategy narratives.

Others have started to examine the role of narratives and storytelling in strategy work. Fenton and Langley (2011) have elaborated on the central role of narratives in the practices of strategy-making. They argue that narratives can be found in the micro-stories of organizational members, in the techniques of strategizing, in the accounts people provide of their work and in the various artefacts produced by strategizing. Küpers, Mantere and Statler (2013) have in turn studied strategy as a lived experience. They focused on three narrative practices in a strategic workshop: discursive struggles over 'hot' words (debates about key terms used in strategy discussions), the de-sacralization of strategy (unraveling the 'sacred' nature of formal strategies) and recurring rituals of selfsacrifice (unraveling of the expected roles and responsibilities of the people involved). Finally, others such as Kaplan and Orlikowski (2013) have focused on temporality in strategy-making and elaborated on how constructions of the past, present and future are a central part of strategy work, thus elucidating the role of narrative in strategy-making.

Narratives have also been found to play a crucial role in strategic change. In a rare empirical analysis, Dunford and Jones (2000) elaborated on the various narratives told by 
senior management in the context of strategic change in three organizations. Their analysis highlighted the role of narrative in top managerial sensegiving and underscored the variations of narratives in the organizations studied, including negative reactions to the narratives told by senior managers. In another empirical study, Brown and Humphreys (2003) found that senior managers explained events in narratives of strategy shifts, whereas two groups of employees provided tragic narratives.

Contribution to stability and change. These studies have provided us with an understanding of how strategy-making involves sensemaking and sensegiving that takes place in and through narratives. Thus, existing strategies can be understood as established narratives (widely shared constructions of the future) and potential new strategies as antenarratives (constructions on possible futures) that are used to bring about strategic change in organizations. Central to this activity is managerial storytelling and the reactions that it triggers and shapes from organizational members. Thus, narrative analyses have considerably added to our understanding of the role of language and communication in strategy-making in general and strategic change in particular (Balogun et al., 2014).

Untapped research questions. There are still few empirical studies elucidating the special characteristics of strategic narratives or the role of storytelling as part of strategymaking processes. Thus, there is a need to elaborate on the narrative ideas and for example study the forms of narrative and processes of strategic storytelling in various empirical contexts. In particular, studying strategy narratives in real time would provide important insights into the convergence and divergence of meaning around specific strategic ideas and initiatives. Empirical analysis of what makes specific strategy 
Narratives as Sources of Stability and Change in Organizations

narratives persuasive or convincing would also enrich our understanding of the effects of strategic storytelling. In addition, a closer analysis of how organizational members may or may not spread the strategy narratives would be valuable to better understand how new strategies may be enacted or resisted.

\section{Narratives and Entrepreneurship}

Narratives have also started to play an increasingly important role in entrepreneurship. This is because narratives provide a natural means for describing entrepreneurial experiences and 'journeys' and because storytelling has been found to be a key part in gathering resources and establishing legitimacy in and around narrative ventures (Garud \& Karnoe, 2003; Gartner, 2007). Thus, the narrative perspective has been promoted as an alternative to the more conventional understandings of entrepreneurship (Garud \& Giuliani, 2013; Hjorth \& Steyaert, 2004).

Illustrative studies. Narrative analyses of entrepreneurship have focused on identity and legitimacy, the implications for resource acquisition, success/failure or critical analysis of the cultural and discursive basis of entrepreneurship (see Table 5 below).

Insert Table 5 around here

Narratives can be seen as an inherent part of entrepreneurial identity and legitimacy. In their seminal study, Lounsbury and Glynn (2001) focused on the storytelling as the means to use cultural resources to establish legitimacy for entrepreneurial ventures. They outline a framework that elaborates how entrepreneurial stories help to establish a new venture identity that serves as a basis for persuading and convincing various stakeholders to support the venture. In another pioneering paper, O’Connor (2002) argued that narratives play a key part in an entrepreneur's identity construction and emphasizes the 
entrepreneur's discursive ability to adopt a position relative to distinct but interconnected plotlines in which various relevant actors figure as key characters.

Narrative studies of entrepreneurship have also frequently examined the crucial role of narratives and storytelling in gaining resources. In particular, Martens et al. (2007) examined the effect of entrepreneurial storytelling on resource acquisition. Their analysis highlighted narrative devices used such as persuasive appeals, elaboration, and familiarity and unfamiliarity. In another study, Navis and Glynn (2011) found that entrepreneurial identities are judged favorably when they are legitimately distinctive and that such judgments are mediated by identity narratives that provide institutional primes and equivocal cues for investor sensemaking. Other studies have then focused on the construction of entrepreneurial opportunities in and through narratives. For instance, Garud and Giuliani (2013) argue for a narrative view in which social, opportunity, and material spaces are woven together. Garud, Schildt and Lant (2014) extend this work by focusing on projective stories that set expectations for new ventures. They particularly highlight the challenge that the very expectations that are set through projective stories to gain legitimacy can also serve as the source of future disappointments.

Others have focused on how entrepreneurs make sense of success and failure. For instance, Mantere et al. (2013) examined narrative attributions in entrepreneurs' accounts of failure. They identified and elaborated on "Catharsis" (personal responsibility), “Hubris” (venture-wide responsibility), “Zeitgeist” (industry-wide responsibility), "Betrayal” (responsible agent inside the venture), "Nemesis" (responsible external agent), "Mechanistic" (uncontrollable non-human element within the venture), and "Fate" (uncontrollable non-human element external to the venture) as distinct types of narrative 
attributions that served particular social functions when coping with the experience of failure. Still others have focused on institutional entrepreneurship, often in relation to the central role of discourse in institutions. For instance, Zilber (2007) has examined the role of stories in the discursive dynamics of institutional entrepreneurship. Her analysis highlights how actors were engaged in constructing a shared story of the crisis that reflected and further strengthened the established institutional order, but also how the same actors were also each telling a counter-story of indictment, blaming other groups for the crisis and calling for changes in the institutional order.

There are also more critical analysis of entrepreneurial narratives. In particular, Hjort and Steyaert (2004) provide an overview various kinds of discursive and narrative perspectives that elucidate the cultural and sociopolitical construction of entrepreneurship. Nicholson and Anderson (2005) have examined the role of myths and metaphors as key parts of the social construction of entrepreneurial culture in the media. Their analysis highlights images of male entrepreneurs as dynamic wolfish charmers, supernatural gurus, successful skyrockets or community saviors and corrupters. Essers and Benschop (2008) in turn focus on the complex processes of identity construction of female ethnic minority entrepreneurs. Their analysis elucidates how identity work varies in the degree of conformity: One type is to mainly to follow conventional images of femininity, another is to denounce femininity and/or ethnicity and a third one is to resist the masculine connotations of entrepreneurship. These analyses thus provide means to critically evaluate the cultural and discursive bases of entrepreneurship.

Contribution to stability and change. Narrative analyses of entrepreneurship help us to better understand entrepreneurial identity, legitimation and resource acquisition. These 
areas highlight how narratives and storytelling promote ventures and thus enable change such as through growth and legitimation. However, narrative analysis also allows us to see how entrepreneurial narratives at times reproduce prevailing understandings of what entrepreneurs and entrepreneurship are like, thus maintaining institutional order.

Untapped research questions. While significant advances have been made with the narrative perspective on entrepreneurship, many issues and questions remained unanswered (Garud \& Giuliani, 2013). For instance, empirical narrative analyses of entrepreneurial opportunity creation are scarce, and little is known about the various cultural aspects of entrepreneurial activities, which could be analyzed by narrative methods. As businesses that often grow substantially over time, there are also important opportunities to trace entrepreneurial narratives as organizations expand or even dissolve. Thus, longitudinal studies of entrepreneurial narratives and storytelling dynamics as well as their comparison across different socio-cultural contexts offer means to significantly advance this literature.

\section{Narratives and Personal Change}

While not as developed as the other topical areas we covered above, scholars have also examined narratives to understand how people interpret their developing selves. A focus on these individual level narratives helps to elucidate the ways in which employees understand their own professional trajectories over time, something that can influence their motivation or other work-related choices (Ibarra, 1999; Kreiner \& Sheep, 2009). Illustrative studies. Narrative analyses of personal change have mostly focused on personal growth and the problems that it entails (see Table 6 below).

Insert Table 6 around here 
In an early study, Roberts, Dutton, Spreitzer, Heaphy \& Quinn (2005) theorized a “reflective best self portrait”-a changing narrative about how people view themselves when they are at their best. They propose that this narrative emerges from social experiences and provides a model of best self development about deliberately changing and growing themselves towards more desirable states. Maitlis (2009) in turn discussed the growth that may emerge from trauma among musicians plagued with a physical condition that required they abandon their profession. Her analysis emphasizes the importance of a positive outlook in the face of setbacks in individual's posttraumatic growth narratives. She found that narratives allow people to understand their identities as they shift and provide an opportunity for positive change. She articulated the processes to construct new identities, which includes a shifting between stability (old self) and change (new self).

Shipp and Jansen (2011) employed a narrative lens to person-environment fit research. The narrative lens is particular helpful to their proposed theory given the scarcity of fit research that has examined change over time. While fit experiences inevitably change over time, and context inevitably shapes these experiences, a shift from psychological perspectives to narrative perspectives highlights both the changing nature of fit, as well as points of stability, and how both aspects are contextually embedded. Another example of personal narratives come from Lawrence and Maitlis (2012) who theorized an 'ethic of care’ based on narrative practices embedded in enduring relationships. They focus on how team members construct their experiences, struggles, and future-oriented stories and identify three caring narrative practices: constructing histories of sparkling moments, contextualizing struggles, and constructing polyphonic 
future- oriented stories.

Building on the theme of positive, self-change, Sonenshein, Dutton, Grant, Spreitzer and Sutcliffe (2013) studied employees working for a financial services, manufacturing and non-profit company to understand how they narrate their growing. They identified three types of growing narratives—achieving, learning and helping. Positioned against predominately psychological theories of growing, the researchers develop theory around how growing narratives are deeply embedded in organizational contexts. Individuals draw from not only personal resources but also contextual resources to construct a narrative about their positive self-change, reflecting their idiosyncratic paths but also drawing from common contextual resources that promote a sense of stability among organizational members. Accordingly, a focus on narratives allows for understanding how even the seemingly personal growth of an individual is nonetheless deeply intertwined with broader organizational (and even societal narratives) that produces common, stable paths out of the unique experiences and choices people make.

Contributions to stability and change. Personal narratives remind researchers that organizations are comprised of individuals who narrate their own experiences at work. Just like organizational narratives unfold dynamics between change and stability, so too do individuals try to use narratives to make sense and give sense of their own experiences at work. However, individuals tell these stories embedded in organizational contexts, suggesting a strong intertwinement of personal narratives that are contextually embedded in organizational narratives. As individuals create meanings of personal growth, they provide opportunities to contribute to organizations that can enhance their capabilities and improve their practices. 
Untapped research questions. We see opportunities for scholars to understand deeper the way in which personal narratives shape organizational narratives. Much of existing research focuses on the way that organizational narratives shape individuals, such as through research on socialization (Saks \& Ashforth, 1997). These contextually embedded personal narratives are important, but personal narratives no doubt also shape organizational ones, and more research is needed to unravel the deep intertwinement between personal and organizational narratives. Furthermore, so far critical streams of narrative research have not been linked with personal growth, although for example criticism of dominant narratives and elaboration of personal resistance and coping strategies are closely related issues.

In summary, we have covered key topic areas that have used narrative research to illuminate dynamics of stability and change. This overview shows richness in the various theoretical perspectives taken and methods used for theorizing and empirically examining narratives. It also points to a number of opportunities in future research.

\section{DIRECTIONS FOR FUTURE RESEARCH}

Drawing on our review, we now outline key areas that warrant additional attention in future research. We identify both theoretical opportunities and methodological opportunities for scholars seeking to use narratives in their research.

\section{Theoretical Opportunities}

Narrative analysis has the potential to advance our understanding of key issues related to stability and change in organizations, but this potential has not yet been fully realized. Thus, we highlight in this section key theoretical opportunities that cut across various topic areas. These include pluralism, reproduction, mobilization, resistance, dialogicality, 
inclusion/exclusion, and temporality.

Pluralism. As an inherently "messy" phenomenon, organizational change frequently unfolds with multiple narratives offered by parties with their own agendas (e.g., Brown, 1998; Creed, Scully \& Austin, 2002; Dawson, 2005). Understanding this pluralism is not only important for researchers seeking to craft their own narratives about what happened but also because narratives reveal how organizational change unfolds as a cacophony of political interests vie to make sense and give sense of change (Gioia \& Chittipeddi, 1991). As should be clear by now, narratives occur at multiple levels of analysis, and scholars usually foreground a subset of these levels, particularly the role of top leader's narratives. Thus, there exist opportunities to integrate theorizing and analysis of these multiple levels of analysis. While interpretative narrative studies have frequently analyzed plurivocality or polyphony, there is a need to connect these multiple voices to organizational processes at multiple levels of analysis to better understand stability and change.

Reproduction. Although a great deal of attention has been focused on particular narratives, the subtle mechanisms of their reproduction warrant more attention in future research. Boje’s (2008) work on antenarratives provides one way to understand how new narratives may emerge among many alternatives, and it can be used to better understand narrative reproduction in various contexts. Dailey and Browning (2014) provide another promising avenue for future research by focusing attention on narrative repetition as a process that plays a key role in explaining how stories spread and how the meaning of these stories shifts over time. In particular, they argue that when stories are retold, some individuals may see them as stability, whereas others may hear a hint of change (see also 
Sonenshein, 2010). Accounting for these diverse narratives, and how they coalesce to advocate for the status quo, or alternatively, push for change, remains a ripe opportunity for additional research.

Mobilization. In addition to understanding how specific narratives are reproduced, it is important to understand how particular narratives may play a crucial role in mobilization for change. In particular, Robichaud, Giroux and Taylor (2004) have outlined a 'metaconversation' perspective that helps to understand the relationship of an overall organizational discourse with various local conversations. Analogically, one can focus attention on new 'metanarratives' that may bring individuals and their own narratives together. This links with the more recent work by Cooren (2010) that focuses on coorientation, i.e., the ability of discourses or narratives to serve as objects that coorient the activities of organizational actors. From this perspective, one can examine how organizational change is related to a production of a coorienting narrative that serves to engage and mobilize people. Future research could examine such processes more closely to better understand how new narratives are created and how individual actors or broader communities engage with this emerging narrative to mobilize for change.

Resistance. Historically, scholars have focused on narratives of resistance that couch any discourse contrary to top management as disruptive of change (Ford et al., 2008). Yet, these narratives not only keep the conversation about change going but also inevitably enrich the dominant narrative of change (Humphreys \& Brown, 2002; Fronda \& Moriceau, 2008; Vaara \& Tienari. 2011). As a result, we see opportunities for scholars to unpack the webs of meaning provided by a range of internal and external stakeholders that try to shape the future trajectory of an organization, whether that involves new 
strategies, products, routines, and so on, or a return to the status quo. For external stakeholders, in an age where the Internet empowers the marginalized with an audience for their stories, scholars have opportunities to locate and understand the impact of these narratives and to contrast them with the 'official' organizational narratives. For example, externally generated narratives from marginalized groups might provoke important change within an organization (e.g., King \& Soule, 2007).

Dialogicality. There is a tendency in narrative analysis to focus on specific narratives or acts of storytelling while their dialogical dynamics have received less attention. Although some narratives may become dominant ones, we argue that a full understanding of the role of narratives in organizational stability and change also requires attention on how they relate to each other in dialogical or dialectical processes. This is because different kinds of narratives are used to promote or resist change. For example, progressive, regressive and stability narratives serve different 'functions' in organizational change (Sonenshein, 2010). Narratives may also draw from different genres depending on their use and purpose in organizational settings. For instance, strategies may be constructed in very different ways in epic, technofuturist and purist narratives (Barry \& Elmes, 1997), and epic and tragic tales provide very different means for making sense of change (Brown \& Humphreys, 2003). A key challenge for future research is thus to examine the dialogical processes between the actors and types of narratives and how they unfold over time as part of organizational stability and change. One interesting avenue for future research is provided by Boje (2008) who has elaborated on the following dialogisms as a basis of narratives: polyphony in terms of multiple voices, stylistic dialogisms in the form of various modes of representation, chronotopes as space-time configurations, and 
Narratives as Sources of Stability and Change in Organizations

architectonic dialogisms shown in the interplay of various cognitive, aesthetic and ethical discourses.

Exclusion/inclusion. Interpretative and poststructuralist scholars have pointed to the need to examine various alternative narratives. In particular, Boje’s (1995) work on Tamara helps to understand how stories may unfold in alternative ways. This perspective has been expanded by Hitchin (2015) by elaborating on the politics of alternative narratives in terms of their implications on how specific voices are privileged and others marginalized. Research that focuses on such exclusion/inclusion is critically important to understanding organizational change where an actor's discourse can frame the direction of the organization and its meaning (e.g., Gioia and Chittipeddi, 1991). In an era of ambiguity, narratives have the opportunities to bring provisional clarity, thereby making inclusion and exclusion dynamics critical to understanding the direction of change or the defense of the status quo.

Temporality. Throughout this review, we have emphasized the special value of narratives to capture the temporal aspects of stability and change. While important advances have been made in the studies referred to above (Cunliffe et al., 2004; Kaplan \& Orlikowski, 2013; Schultz \& Hernes, 2013), there is a need for additional research to understand better the various ways in which temporality features in narratives of stability and change and how storytelling in turn structures the temporal unfolding of organizational change. Ricœur’s (1983) classical work emphasizes the inherent potential of narratives to capture different understandings of temporal orientation, but this stream of research has been largely untapped in organizational narrative analysis. Bakhtin has written about chronotopes, that is space-time configurations in narratives, which has 
Narratives as Sources of Stability and Change in Organizations

inspired only limited work along these lines (Pedersen, 2009). Boje (2008) has pointed to different temporal forms of narratives (including linear, cyclical, spiral and rhizomatic types), but little research has so far examined these types or their interrelationships. Thus, there is much more to temporality in organizational stability and change that can and should be examined in future research.

\section{Methodological Challenges}

While there already are a variety of methodological applications of narrative analysis, we highlight three key issues that warrant attention in future research: transparency and reflection in the composition of narratives, the use of new forms of empirical material, and new tools of analysis and representation.

Transparency and reflection in composition. Given the complexity of organizational narratives, their identification, selection and representation is a demanding issue that has received inadequate attention in organization studies. An important part of conducting qualitative research is for the author to construct his or her own narrative (Golden-Biddle and Locke, 2007; Jarzabkowski et al., 2014), and it becomes incumbent on scholars to piece the fragments of alternative organizational narratives together and to reflect on the extent to which these capture the fully array of actors offering narratives as well as explaining the variety of types of narratives told to shape change and stability inside organizations. This challenge is of utmost importance for realist narrative analysis that seeks to provide an authentic description of sequences of events and processes.

Interpretative scholars face the same issue in another way as they typically create composite narratives that piece narrative fragments together. Finally, for poststructuralist scholars, critical analysis of dominant and alternative narratives is a major goal but what 
narratives are chosen and elaborated on remains a crucial issue. We think the best direction involves transparency and methodological reflection in narrative analysis to highlight the key choices made in collecting, analyzing and presenting narratives. We encourage scholars to provide this crucial information in methods sections.

New forms of empirical material. The focus of contemporary narrative research has been on written texts (reflecting the literary tradition or linguistic analysis) or oral communication (representing the folkloristic tradition), and this type of discourse in textual form has been the dominant means to understand the dynamics of stability and change. While this type of data has helped unearth important insights about change and stability, several potentially valuable sources of data remain under-examined. In addition to written texts or oral communication, organizational narratives can involve video, sound and other forms of semiosis (Meyer et al., 2013; Kress \& van Leeuwen, 1996). For example, videos might better capture the valence of narratives because of their richer ability to account for emotions. The changing emotional tone for an organization can provide important clues about change (Huy, 2002), including stability (emotions such as calmness) or turbulence (emotions such as anxiety). Videos also allow leaders of an organizational change to disperse their message to a wider audience, something that can extend the reach of narratives to broader areas of the organization. For example, Young and Post (1993) found that video communications often privilege a top management perspective on change. An analysis of these forms of narrative may unpack important power dynamics that promote stability (e.g., positive interpretations of an organization's status quo) or generate change (e.g., create urgency by alerting employees to the dangers of the status quo) using video, but scholars may also want to examine how video data 
provides an equally important means for employees to push back during change, such as through dispensing these narratives via social media. Other alternative data sources include photographs, which offer a snapshot in time that momentarily freezes a phenomenon, process or practice. Sørensen (2014) recently used photographs in his analysis of organizational aesthetics. Visual presentations such as PowerPoint presentations provide another important source of narrative data (e.g., Kaplan, 2011) scholars have too infrequently acknowledged. Finally, such analysis can also illuminate the role of embodied narrative sensemaking as in the form of gestures or bodily movements (Cunliffe \& Coupland, 2011).

Due to technological advances, new forms of narratives and storytelling have also emerged, and this especially the case with the mass and social media. There already are narrative analyses that draw on mass media (Boje et al., 2004; Vaara \& Tienari, 2011), but there is room for increasingly comprehensive and sophisticated analyses that would be able to harness the richness of media coverage around organizational phenomena. Social media provides a largely untapped source of narrative data, where text, picture, video, and so on are often intertwined. Already, researchers have used narratives from crowdfunding websites to capture the stories individuals tell to acquire resources to positively change their business or selves (Herzenstein et al., 2011). Given the amount of narratives that exist on the Internet, scholars have opportunities to study the formation and spread of these narratives and how they shape organizational life. More detailed and richer modes of narratives may make more interesting and theoretically rich data but scholars are just beginning to experiment with how best to use this material.

New tools of narrative analysis and representation. While narrative analysis has 
usually been associated with qualitative analysis, it is also important to emphasize the potential of more systematic forms of analysis that can deal with large amounts of different types of data. There are examples of tools used especially in realist narrative analysis, but in many ways narrative scholars have been shy to make use of the potential offered by recent software development. Yet qualitative software such as NVivo now allow for video coding that could be very useful for multimodal narrative analysis. Although for example Pentland and Feldman (2007) have outlined a network-based approach to study the interlinkages of narratives in networks of texts, the potential of textual network analysis has not been realized in narrative studies. There are also other computer- or software-based forms of analysis that could help organizational narrative analysis to reap the potential of larger corpuses such as media material. Such forms of analysis and tools may also be used as first steps in analyses to map out broader patterns even if the focus would be on close qualitative analysis of the role of specific narratives in organizational stability and change.

Furthermore, journals are starting to experiment with presenting richer modes narratives to accompany texts. For example, the Academy of Management Journal is currently experimenting with embedding video and audio in electronic versions of papers. As technology continues to advance in ways that allow for the presentation of scholarly narratives beyond the written text, we will likely see more creativity with the sources of data that take us beyond traditional narrative modes.

\section{CONCLUSION}

Narratives research has developed a great deal over the past few decades. Our hope is that by providing a guided tour of the diverse perspectives on organizational narrative 
analysis, we have presented a useful overview of this potentially generative but also occasionally intimidating body of knowledge.

In this review, we have focused on the key role of narratives in understanding stability and change in organizations. Narratives allow scholars to understand, describe and ultimately explain dynamics between stability and change, whether at the micro, meso or macro levels. A focus on temporal discursive sensemaking and sensegiving uniquely position narratives to unpack a core duality of stability and change that pervades theories of organizing, organizational theory and organizational behavior. This has made us emphasize temporality as a key characteristic of narratives, which reveals important aspects of stability and change, and focus attention on the power of narratives to influence organizational processes.

By outlining the underlying assumptions to three core narrative approachesrealist, interpretive, and poststructuralist—we have offered specific starting points to engage with organizational narrative research, reflecting distinctive epistemological and ontological foundations as well as methodological choices. As we have shown, there are many opportunities for narrative research to continue to flourish and grow from multiple perspectives. While narratives have become a key part of specific topic areas such as research on organizational change or identity, their full potential remains to be unleashed. Moreover, in areas such as strategy-making theoretical advances with narratives have not yet been followed by a significant body of empirical research. In other areas such as entrepreneurship or personal change, there are also blank spots that narrative studies could at least partially fill.

In this paper, we have also focused on themes that can advance organizational 
narrative perspectives, both theoretically and methodologically. By developing narrative theorizations and methods along such lines, we can not only advance narrative applications in organization studies, but also develop organizational narrative analysis as an area that can contribute to the broader field of narrative and discursive studies in social sciences. 
Narratives as Sources of Stability and Change in Organizations

\section{REFERENCES}

Abbott, A. (1992). From causes to events: Notes on narrative positivism. Sociological Methods \& Research, 20(4), 428-455.

Adorisio, A.L.M. (2014). Organizational remembering as narrative: 'Storying' the past in banking. Organization Studies, 21(4), 463-476.

Bakhtin, M. (1981). The dialogic imagination. Four essays by MM Bakhtin. Austin, TX: University of Texas Press.

Balogun, J., \& Johnson, G. (2004). Organizational restructuring and middle management sensemaking. Academy of Management Journal, 47(4), 523-549.

Balogun, J., Jacobs, C., Jarzabkowski, P., Mantere, S., \& Vaara, E. (2014). Placing strategy discourse in context: Sociomateriality, sensemaking, and power. Journal of Management Studies, 51(2), 175-201.

Barry, D., \& Elmes, M. (1997). Strategy retold: Toward a narrative view of strategic discourse. Academy of Management Review, 22(2), 429-452.

Bartel, C., \& Garud, R. (2009). The role of narratives in sustaining organizational innovation. Organization Science, 20(1), 107-117.

Beech, N., MacPhail, S., \& Coupland, C. (2009). Anti-dialogic Positioning in Change Stories: Bank Robbers, Saviours and Peons. Organization, 16(3), 335-352.

Belova, O., King, I., \& Sliwa, M. (2008). Introduction: Polyphony and organization studies: Mikhail Bakhtin and Beyond. Organization Studies, 29(4), 493-500.

Boje, D. (1991). The storytelling organization: A study of story performance in an office-supply firm. Administrative Science Quarterly, 36(1), 106-126.

Boje, D. (1995). Stories of the storytelling organization: a postmodern analysis of Disney as "Tamara-land". Academy of Management Journal, 38(4), 997-1035. 
Boje, D. (2008). Storytelling organizations. London: Sage.

Boje, D. (2011). Storytelling and the future of organizations. New York: Routledge.

Boje, D. (2014). Storytelling organizational practices: Managing in the quantum age. New York: Routledge.

Boje, D., Rosile, G., Durant, R., \& Luhman, J. (2004). Enron spectacles: A critical dramaturgical analysis. Organization Studies, 25(5), 751-774.

Boland, R., \& Tenkasi, R. (1995). Perspective making and perspective taking in communities of knowing. Organization Science, 6(4), 350-372.

Brown, A. (1998). Narrative, politics and legitimacy in an IT implementation. Journal of Management Studies, 35(1), 35-58.

Brown, A. (2003). Epic and tragic tales: Making sense of change. Journal of Applied Behavioral Science, 39(2), 121-144.

Brown, A. (2006). A narrative approach to collective identities. Journal of Management Studies, 43(4), 731-753.

Brown, A., \& Humphreys, M. (2003). Epic and tragic tales: Making sense of change. Journal of Applied Behavioral Science, 39(2), 121-144.

Brown, A., Humphreys, M., \& Gurney, P. (2005). Narrative, identity and change: A case study of Laskarina Holidays. Journal of Organizational Change Management, 18(4), 312-326.

Bruner, J. (1986). Actual minds, possible worlds. Cambridge, Mass: Harvard University Press.

Bruner, J. (1990). Acts of meaning. Cambridge, Mass: Harvard University Press.

Buchanan, D. (2003). Demands, instabilities, manipulations, careers: The lived experience of driving change. Human Relations, 56(6), 663-684.

Buchanan, D., \& Dawson, P. (2007). Discourse and audience: Organizational change as multi- 
Narratives as Sources of Stability and Change in Organizations

story process. Journal of Management Studies, 44(5), 669-686.

Burgelman, R. (2011). Bridging history and reductionism: A key role for longitudinal qualitative research. Journal of International Business Studies, 42(5), 591-601.

Carlsen, A. (2006). Organizational becoming as dialogic imagination of practice: The case of the indomitable Gauls. Organization Science, 17(1), 132-149.

Cheney, G., Christensen Thoger, L., Conrad, C., \& Lair, D. (2004). Corporate rhetoric as organizational discourse. In D. Grant, C. Hardy, C. Oswick \& L. Putnam, The Sage handbook of organizational discourse (1st ed., pp. 79-103). Thousand Oaks, CA: Sage.

Chia, R. (1999). A ‘rhizomic’ model of organizational change and transformation: Perspective from a metaphysics of change. British Journal of Management, 10(3), 209-227.

Chreim, S. (2005). The continuity-change duality in narrative texts of organizational identity. Journal of Management Studies, 42(3), 567-593.

Chreim, S. (2007). Social and temporal influences on interpretations of organizational identity and acquisition integration: A narrative study. Journal of Applied Behavioral Science, 43(4), 449-480.

Collins, D., \& Rainwater, K. (2005). Managing change at Sears: A sideways look at a tale of corporate transformation. Journal of Organizational Change Management, 18(1), 16-30.

Cooren, F. (2010). Action and agency in dialogue. Amsterdam: John Benjamins Pub. Co.

Cornelissen, J., \& Werner, M. (2014). Putting framing in perspective: A review of framing and frame analysis across the sensemaking, social movements and institutional literatures. Academy of Management Annals, 8(1), 181-235.

Creed, W., Scully, M., \& Austin, J. (2002). Clothes make the person? The tailoring of legitimating accounts and the social construction of identity. Organization Science, 13(5), 475-496. 
Narratives as Sources of Stability and Change in Organizations

Cunliffe, A., \& Coupland, C. (2011). From hero to villain to hero: Making experience sensible through embodied narrative sensemaking. Organization Studies, 25(2), 261-286.

Cunliffe, A., Luhman, J., \& Boje, D. (2004). Narrative temporality: Implications for organizational research. Organization Studies, 25(2), 261-286.

Currie, G., \& Brown, A. (2003). A narratological approach to understanding processes of organizing in a UK hospital. Human Relations, 56(5), 563-586.

Czarniawska-Joerges, B. (1997). Narrating the organization. Chicago: University of Chicago Press.

Czarniawska-Joerges, B. (2004). Narratives in social science research. London: Sage Publications.

Dailey, S., \& Browning, L. (2014). Retelling stories in organizations: Understanding the functions of narrative repetition. Academy of Management Review, 39(1), 22-43.

Dawson, P. (2005). The way it really happened: Competing narratives in the political process of technological change. Human Relations, 58(7), 845-865.

Driver, M. (2009). Struggling with lack: A Lacanian perspective on organizational identity. Organization Studies, 30(1), 55-72.

Dunford, R., \& Jones, D. (2000). Narrative in strategic change. Human Relations, 53(9), 12071226.

Essers, C, \& Benschop, Y (2008). Enterprising identities: Turkish origin in the Netherlands. Organization Studies, 28(1), 49-69.

Farjoun, M. (2010). Beyond dualism: stability and change as duality. Academy of Management Review, 35(2), 202-225.

Feldman, M. (2000). Organizational routines as a source of continuous change. Organization Science, 11(6), 611-629. 
Narratives as Sources of Stability and Change in Organizations

Fenton, C., \& Langley, A. (2011). Strategy as practice and the narrative turn. Organization Studies, 32(9), 1171-1196.

Fiol, C. (2002). Capitalizing on paradox: The role of language in transforming organizational identities. Organization Science, 13(6), 653-666.

Ford, J., Ford, L., \& D’Amelio, A. (2008). Resistance to change: The rest of the story. Academy of Management Review, 33(2), 362-377.

Fronda, Y., \& Moriceau, J. (2008). I am not your hero: Change management and culture shocks in a public sector corporation. Journal of Organizational Change Management, 21(5), 589609.

Gabriel, Y. (2000). Storytelling in organizations. Oxford: Oxford University Press.

Gabriel, Y., Gray, D., \& Goregaokar, H. (2010). Temporary derailment or the end of the line? Managers coping with unemployment at 50. Organization Studies, 31(12), 1687-1712.

Gartner, W. B. (2007). Entrepreneurial narrative and a science of the imagination. Journal of Business Venturing, 22: 613-627.

Garud, R., \& Giuliani, A. (2013). A narrative perspective on entrepreneurial opportunities. Academy of Management Review, 38(1), 157-160.

Garud, R., \& Karnoe, P. (2003). Bricolage versus breakthrough: distributed and embedded agency in technology entrepreneurship. Research Policy, 32(2), 277-300.

Garud, R., Dunbar, R., \& Bartel, C. (2011). Dealing with unusual experiences: A narrative perspective on organizational learning. Organization Science, 22(3), 587-601

Garud, R., Schildt, H., \& Lant, T. (2014). Entrepreneurial storytelling, future expectations, and the paradox of legitimacy. Organization Science, 25(5), 1479-1492.

Gergen, K., \& Gergen, M. (1997). Narratives of the self. In L. Hinchman \& S. Hinchman, Memory, identity, community: The idea of narrative in the human sciences (1st ed., pp. 161- 
184). Albany: State University of New York.

Gertsen, M., \& Søderberg, A. (2011). Intercultural collaboration stories: On narrative inquiry and analysis as tools for research in international business. Journal of International Business Studies, 42(6), 787-804.

Gioia, D., \& Chittipeddi, K. (1991). Sensemaking and sensegiving in strategic change initiation. Strategic Management Journal, 12(6), 433-448.

Golden-Biddle, L., \& Locke, K. (2007). Composing qualitative research. Thousand Oaks, CA: Sage.

Greimas, A. (1987). On meaning. Minneapolis: University of Minnesota Press.

Griffin, L. (1993). Narrative, event-structure analysis, and causal interpretation in historical sociology. American Journal of Sociology, 98(5), 1094-1133.

Haack, P., Schoeneborn, D., \& Wickert, C. (2012). Talking the talk, moral entrapment, creeping commitment? Exploring narrative dynamics in corporate responsibility standardization. Organization Studies, 33(5-6), 815-845.

Herzenstein, M., Sonenshein, S., \& Dholakia, U. (2011). Tell me a good story and I may lend you my money: The role of narratives in peer-to-peer lending decisions. Journal of Marketing Research, 48, 138-149.

Hitchin, L. (2015). Method and story fragments: Working through untold method. In M. Izak, L. Hitchin \& D. Anderson, Untold stories in organizations (1st ed., pp. 213-238). New York: Routledge.

Hjorth, D., \& Steyaert, C. (2004). Narrative and discursive approaches in entrepreneurship. Cheltenham: Edward Elgar.

Humphreys, M., \& Brown, A. (2002). Dress and identity: A Turkish case study. Journal of Management Studies, 39(7), 927-952. 
Narratives as Sources of Stability and Change in Organizations

Humphreys, M., \& Brown, A. (2002). Narratives of organizational identity and identification: A case study of hegemony and resistance. Organization Studies, 23(3), 421-447.

Huy, Q. (2002). Emotional balancing of organizational continuity and radical change: The contribution of middle managers. Administrative Science Quarterly, 47(1), 31-69.

Ibarra, H. (1999). Provisional selves: Experimenting with image and identity in professional adaptation. Administrative Science Quarterly, 44(4), 764-791.

Ibarra, H., \& Barbulescu, R. (2010). Identity as narrative: prevalence, effectiveness and consequences of narrative identity work in macro work role transitions. Academy of Management Review, 35(1), 135-154.

Jarzabkowski, P., Bednarek, R., \& Lê, J. (2014). Producing persuasive findings: Demystifying ethnographic textwork in strategy and organization research. Strategic Organization, 12(4), 274-287.

Kaplan, S. (2011). Strategy and PowerPoint: An inquiry into the epistemic culture and machinery of strategy making. Organization Science, 22(2), 320-346.

Kaplan, S., \& Orlikowski, W. (2013). Temporal work in strategy making. Organization Science, 24(4), 965-995.

King, B. (2007). Social movements as extra institutional entrepreneurs: The effect of protest on stock price returns. Administrative Science Quarterly, 52(3), 413-442.

Koerner, M. (2014). Courage as identity work: Accounts of workplace courage. Academy of Management Journal, 57(1), 63-93.

Kreiner, G., \& Sheep, M. (2009). Growing pains and gains: Framing identity dynamics as opportunities for identity growth. In L. Roberts \& J. Dutton, Exploring positive identities and organizations (1st ed., pp. 24-43). New York: Routledge.

Kress, G., \& Van Leeuwen, T. (1996). Reading images. London: Routledge. 
Narratives as Sources of Stability and Change in Organizations

Küpers, W., Mantere, S., \& Statler, M. (2013). Strategy as storytelling: A phenomenological collaboration. Journal of Management Inquiry, 22(1), 83-100.

Langley, A. (1999). Strategies for theorizing from process Data. Academy of Management Review, 24(4), 691.

Lawrence, T., \& Maitlis, S. (2012). Care and possibility: Enacting an ethic of care through narrative practice. Academy of Management Review, 37(4), 641-663.

Loewenstein, J., Ocasio, W., \& Jones, C. (2012). Vocabularies and vocabulary structure: A new approach linking categories, practices, and institutions. Academy of Management Annals, 6(1), 41-87.

Lounsbury, M., \& Glynn, M. (2001). Cultural entrepreneurship: stories, legitimacy, and the acquisition of resources. Strategic Management Journal, 22(6-7), 545-564.

Lyotard, J. (1979). The postmodern condition: A report on knowledge (10th ed.). Minnesota: University of Minnesota Press.

Maguire, S., \& Phillips, N. (2008). 'Citibankers' at Citigroup: A study of the loss of institutional trust after a merger. Journal of Management Studies, 45(2), 372-401.

Maitlis, S. (2009). Who am I now? Sensemaking and identity in posttraumatic growth. In L. Roberts \& J. Dutton, Exploring positive identities and organizations: Building a theoretical and research foundation (1st ed., pp. 47-76). New York: Routledge.

Mantere, S., Aula, P., Schildt, H., \& Vaara, E. (2013). Narrative attributions of entrepreneurial failure. Journal of Business Venturing, 28(4), 459-473.

Martens, M., Jennings, J., \& Jennings, P. (2007). Do the stories they tell get them the money they need? The role of narratives in resource acquisition. Academy of Management Journal, 50(5), 1107-1132.

Martin, J. (1990). Deconstructing organizational taboos: The suppression of gender conflict in organizations. Organization Science, 1(4), 339-359. 
Narratives as Sources of Stability and Change in Organizations

Martin, J., Feldman, M., Hatch, M., \& Sitkin, S. (1983). The uniqueness paradox in organizational stories. Administrative Science Quarterly, 28(3), 438.

Martin, S (In Press). Stories about values and valuable stories: A field experiment of the power of narratives to shape newcomers’ actions.” Academy of Management Journal.

Meyer, R., Höllerer, M., Jancsary, D., \& van Leeuwen, T. (2013). The visual dimension in organizing, organization, and organization research: Core ideas, current developments, and promising avenues. Academy of Management Annals, 7(1), 489-555.

Morris, M., \& Moore, P. (2000). The lessons we (don't) learn: Counterfactual thinking and organizational accountability after a close call. Administrative Science Quarterly, 45(4), 737-765.

Morson, G. (1994). Narrative and freedom. New Haven: Yale University Press.

Navis, C., \& Glynn, M. (2011). Legitimate distinctiveness and the entrepreneurial identity: Influence on investor judgments of new venture plausibility. Academy of Management Review, 36(3), 479-499.

Nicholson, L., \& Anderson, A. (2005). News and nuances of the entrepreneurial myth and metaphor: Linguistic games in entrepreneurial sense-making and sense-giving. Entrepreneurship Theory and Practice, 29(2), 153-172.

O’Connor, E. (2002). Storied business: typology, intertextuality, and traffic in entrepreneurial narrative. Journal of Business Communication, 39(1), 36-54.

Oswick, C., Anthony, P., Keenoy, T., Mangham, I., \& Grant, D. (2000). A dialogic analysis of organizational learning. Journal of Management Studies, 37(6), 887-902.

Patriotta, G. (2003). Sensemaking on the shop floor: Narratives of knowledge in organizations*. Journal of Management Studies, 40(2), 349-375.

Pedersen, A. (2009). Moving away from chronological time: Introducing the shadows of time and chronotopes as new understandings of `narrative time'. Organization, 16(3), 389-406. 
Narratives as Sources of Stability and Change in Organizations

Pentland, B. (1999). Building process theory with narrative: From description to explanation. Academy of Management Review, 24(4), 711-724.

Pentland, B., \& Feldman, M. (2007). Narrative networks: Patterns of technology and organization. Organization Science, 18(5), 781-795.

Phillips, N., \& Oswick, C. (2012). Organizational discourse: domains, debates, and directions. Academy of Management Annals, 6(1), 435-481.

Phillips, M., Pullen, A., \& Rhodes, C. (2014). Writing organizations as gendered practice: Interrupting the libidinal economy. Organization Studies, 35(3), 313-333.

Polkinghorne, D. (1988). Narrative knowing and the human sciences. New York: State University of New York Press.

Propp, V. (1968). Morphology of the folktale. Austin: University of Texas Press.

Reissner, S. C. (2011). Patterns of stories of organisational change. Journal of Organizational Change Management, 24(5): 593-609.

Reissner, S. C., \& Pagan, V. (2013). Storytelling in management practice: Dynamics and implications. London: Routledge.

Rhodes, C., \& Brown, A. (2005). Narrative, organizations and research. International Journal of Management Reviews, 7(3), 167-188.

Rhodes, C., Pullen, A., \& Clegg, S. (2010). 'If I should fall from grace’ Stories of change and organizational ethics. Journal of Business Ethics, 91(4), 535-551.

Ricoeur, P. (1983). Time and narrative. Trans. K McLaughlin and D. Pellauer. Chicago: University of Chicago press.

Roberts, L., Dutton, J., Spreitzer, G., Heaphy, E., \& Quinn, R. (2005). Composing the reflected best-self portrait: Building pathways for becoming extraordinary in work organizations. Academy of Management Review, 30(4), 712-736. 
Narratives as Sources of Stability and Change in Organizations

Robichaud, D., Giroux, H., \& Taylor, J. (2004). The Metaconversation: The recursive property of language as a key to organizing. Academy of Management Review, 29(4), 617-634.

Rosile, G., Boje, D., Carlon, D., Downs, A., \& Saylors, R. (2013). Storytelling diamond: An antenarrative integration of the six facets of storytelling in organization research design. Organizational Research Methods, 16(4), 557-580.

Saks, A., \& Ashforth, B. (1997). Organizational socialization: Making sense of the past and present as a prologue for the future. Journal of Vocational Behavior, 51(2), 234-279.

Schultz, M., \& Hernes, T. (2013). A temporal perspective on organizational identity. Organization Science, 24(1), 1-21.

Shipp, A., \& Jansen, K. (2011). Reinterpreting time in fit theory: Crafting and recrafting narratives of fit in medias res. Academy Of Management Review, 36(1), 76-101.

Sköldberg, K. (1994). Tales of change: Public administration reform and narrative mode. Organization Science, 5(2), 219-238.

Sonenshein, S. (2006). Crafting social issues at work. Academy of Management Journal, 49(6), 1158-1172.

Sonenshein, S. (2009). Emergence of ethical issues during strategic change implementation. Organization Science, 20(1), 223-239.

Sonenshein, S. (2010). We're changing--or are we? Untangling the role of progressive, regressive, and stability narratives during strategic change implementation. Academy of Management Journal, 53(3), 477-512.

Sonenshein, S., \& Dholakia, U. (2012). Explaining employee engagement with strategic change implementation: A meaning-making approach. Organization Science, 23(1),1-23.

Sonenshein, S., Dutton, J., Grant, A., Spreitzer, G., \& Sutcliffe, K. (2013). Growing at work: Employees' interpretations of progressive self-change in organizations. Organization Science, 24(2), 552-570. 
Narratives as Sources of Stability and Change in Organizations

Sorensen, B. (2014). Changing the memory of suffering: An organizational aesthetics of the dark side. Organization Studies, 35(2), 279-302.

Stevenson, W., \& Greenberg, D. (1998). The formal analysis of narratives of organizational change. Journal of Management, 24(6), 741-762.

Tsoukas, H., \& Chia, R. (2002). On organizational becoming: Rethinking organizational change. Organization Science, 13(5), 567-582.

Vaara, E. (2002). On the discursive construction of success/failure in narratives of post-merger integration. Organization Studies, 23(2), 211-248.

Vaara, E., \& Pedersen, A. (2014). Strategy and chronotopes: a Bakhtinian perspective on the construction of strategy narratives.M@N@Gement,16(5),593-604.

Vaara, E., \& Tienari, J. (2011). On the narrative construction of multinational corporations: An antenarrative analysis of legitimation and resistance in a cross-border merger. Organization Science, 22(2), 370-390.

Van de Ven, A., \& Huber, G. (1990). Longitudinal field research methods for studying processes of organizational change. Organization Science, 1(3), 213-219.

Van Maanen, J. (1988). Tales of the field. Chicago: University of Chicago Press.

Weick, K. (1979). The social psychology of organizing. Reading, MA: Addison-Wesley.

Whittle, A., Mueller, F., \& Mangan, A. (2009). Storytelling and `character': Victims, villains and heroes in a case of technological change. Organization, 16(3), 425-442.

Wright, C., Nyberg, D., \& Grant, D. (2012). "Hippies on the third floor": Climate change, narrative identity and the micro-politics of corporate environmentalism. Organization Studies, 33(11), 1451-1475.

Wry, T., Lounsbury, M., \& Glynn, M. (2011). Legitimating nascent collective identities: Coordinating cultural entrepreneurship. Organization Science, 22(2), 449-463. 
Narratives as Sources of Stability and Change in Organizations

Ybema, S. (2010). Talk of change: temporal contrasts and collective identities. Organization Studies, 31(4), 481-503.

Young, M., \& Post, J. (1993). Managing to communicate, communicating to manage: How leading companies communicate with employees. Organizational Dynamics, 22(1), 31-43.

Zilber, T. (2007). Stories and the discursive dynamics of institutional entrepreneurship: The case of Israeli high-tech after the bubble. Organization Studies, 28(7), 1035-1054. 


\section{Table 1: Narrative approaches to Organizational Stability and Change}

\begin{tabular}{|c|c|c|c|c|c|}
\hline & Approach to research & $\begin{array}{l}\text { Onto-epistemological } \\
\text { role of narratives }\end{array}$ & $\begin{array}{l}\text { Theoretical sources of } \\
\text { inspiration }\end{array}$ & Methods & $\begin{array}{l}\text { Contributions to } \\
\text { stability and change }\end{array}$ \\
\hline Realist approaches & $\begin{array}{l}\text { Traditional science: } \\
\text { narratives are used to } \\
\text { understand phenomena } \\
\text { that exist independently of } \\
\text { the narratives per se }\end{array}$ & $\begin{array}{l}\text { Narratives as researchers' } \\
\text { constructions of } \\
\text { organizational processes } \\
\text { Narratives as sources of } \\
\text { data to capture } \\
\text { organizational and } \\
\text { managerial phenomena }\end{array}$ & $\begin{array}{l}\text { Various sociological, } \\
\text { organizational and } \\
\text { managerial theories } \\
\text { Focus on using narratives } \\
\text { as sources of data }\end{array}$ & $\begin{array}{l}\text { Realist qualitative case } \\
\text { analysis } \\
\text { Positivist qualitative and } \\
\text { quantitative methods }\end{array}$ & $\begin{array}{l}\text { Longitudinal } \\
\text { representations of } \\
\text { stability and change } \\
\text { Analyses of the effects of } \\
\text { narratives on other } \\
\text { phenomena }\end{array}$ \\
\hline $\begin{array}{l}\text { Interpretative } \\
\text { approaches }\end{array}$ & $\begin{array}{l}\text { Social construction in and } \\
\text { through narratives: } \\
\text { narratives (and narrative } \\
\text { methodology) are in the } \\
\text { center of the analysis }\end{array}$ & $\begin{array}{l}\text { Individual narratives as } \\
\text { objects of study per se } \\
\text { Interpretative patterns as } \\
\text { key elements across } \\
\text { narratives }\end{array}$ & $\begin{array}{l}\text { Various narrative } \\
\text { traditions in psychology, } \\
\text { sociology, literary theory } \\
\text { and linguistics } \\
\text { Sensemaking theory }\end{array}$ & $\begin{array}{l}\text { Various forms of } \\
\text { narrative analysis as } \\
\text { informed by psychology, } \\
\text { sociology, literary theory } \\
\text { and linguistics } \\
\text { Analysis of individual } \\
\text { narratives or } \\
\text { interpretative patterns to } \\
\text { form composite } \\
\text { narratives }\end{array}$ & $\begin{array}{l}\text { Construction of narratives } \\
\text { Plurivocality/polyphony }\end{array}$ \\
\hline
\end{tabular}


Narratives as Sources of Stability and Change in Organizations

\begin{tabular}{|c|c|c|c|c|c|}
\hline $\begin{array}{l}\text { Poststructuralist } \\
\text { approaches }\end{array}$ & $\begin{array}{l}\text { Radical social } \\
\text { constructionism: critique } \\
\text { on prevailing narratives } \\
\text { and innovative theory } \\
\text { building in terms of } \\
\text { discovery of new kinds of } \\
\text { narrative }\end{array}$ & $\begin{array}{l}\text { Deconstruction of } \\
\text { prevailing or dominant } \\
\text { narratives } \\
\text { Narratives as key elements } \\
\text { in organizational ontology } \\
\text { and becoming }\end{array}$ & $\begin{array}{l}\text { Poststructuralism and } \\
\text { postmodernism } \\
\text { Critical organizational } \\
\text { analysis }\end{array}$ & $\begin{array}{l}\text { Poststructuralist } \\
\text { discourse and narrative } \\
\text { analysis } \\
\text { 'Strong' processual } \\
\text { analysis (e.g., } \\
\text { antenarrative) }\end{array}$ & $\begin{array}{l}\text { Critical analysis of } \\
\text { hegemonic presentation } \\
\text { Uncovering or } \\
\text { marginalized } \\
\text { perspectives or voices } \\
\text { Narrative performativity } \\
\text { Role of narratives in } \\
\text { organizational } \\
\text { emergence and becoming }\end{array}$ \\
\hline
\end{tabular}


Table 2: Narratives and Organizational Change

\begin{tabular}{|c|c|c|c|c|c|}
\hline & Approach & Focus & Theoretical basis & Methods & $\begin{array}{l}\text { Main findings / implications for stability } \\
\text { and change }\end{array}$ \\
\hline $\begin{array}{l}\text { Boje (1991): The } \\
\text { storytelling } \\
\text { organization: A study } \\
\text { of story performance } \\
\text { in an office-supply } \\
\text { firm }\end{array}$ & $\begin{array}{l}\text { Interpretative/ } \\
\text { poststructuralist }\end{array}$ & $\begin{array}{l}\text { Organizational } \\
\text { change and } \\
\text { storytelling }\end{array}$ & $\begin{array}{l}\text { Storytelling and } \\
\text { sensemaking }\end{array}$ & $\begin{array}{l}\text { Ethnographic study of } \\
\text { conversations in a large } \\
\text { office-supply firm }\end{array}$ & $\begin{array}{l}\text { A theory of organizations as a collective } \\
\text { storytelling system where stories are a key } \\
\text { part of storytelling } \\
\text { Stories were frequently challenged, } \\
\text { reinterpreted and revised by the hearers as } \\
\text { they unfolded in conversations }\end{array}$ \\
\hline $\begin{array}{l}\text { Sköldberg (1994): } \\
\text { Tales of change: } \\
\text { Public administration } \\
\text { reform and narrative } \\
\text { mode }\end{array}$ & Interpretative & $\begin{array}{l}\text { Organizational change } \\
\text { (in the public sector) }\end{array}$ & $\begin{array}{l}\text { Institutional and } \\
\text { narrative theories }\end{array}$ & $\begin{array}{l}\text { Case studies of change in } \\
\text { Swedish local authorities }\end{array}$ & $\begin{array}{l}\text { Identification of and elaboration on three } \\
\text { types of narrative modes: tragedy, romantic } \\
\text { comedy and satire } \\
\text { Narrative conventions and their genres, } \\
\text { rather than more substantial concerns, } \\
\text { formed the texture of the changes for the } \\
\text { people involved }\end{array}$ \\
\hline $\begin{array}{l}\text { Vaara (2002): On the } \\
\text { discursive } \\
\text { construction of } \\
\text { success/failure in } \\
\text { narratives of post- } \\
\text { merger integration }\end{array}$ & Interpretative & $\begin{array}{l}\text { Post-merger } \\
\text { organizational change }\end{array}$ & $\begin{array}{l}\text { Narrative and } \\
\text { attribution theory }\end{array}$ & $\begin{array}{l}\text { Narratives analysis of } \\
\text { accounts of postmerger } \\
\text { integration processes }\end{array}$ & $\begin{array}{l}\text { Distinguishing four types of discourses: } \\
\text { rationalistic, cultural, role-bound and } \\
\text { individualistic } \\
\text { Narratives enable specific (discursive) } \\
\text { strategies for (re)framing the success/failure, } \\
\text { justification/legitimization of one's own } \\
\text { actions, and (re)construction of } \\
\text { responsibility when dealing with socio- } \\
\text { psychological pressures associated with } \\
\text { success/failure }\end{array}$ \\
\hline
\end{tabular}




\begin{tabular}{|c|c|c|c|c|c|}
\hline $\begin{array}{l}\text { Carlsen (2006): } \\
\text { Organizational } \\
\text { becoming as dialogic } \\
\text { imagination of } \\
\text { practice: The case of } \\
\text { the Indomitable Gauls }\end{array}$ & Poststructuralist & $\begin{array}{l}\text { Organizational change } \\
\text { and identity }\end{array}$ & $\begin{array}{l}\text { Process and practice } \\
\text { theories and narrative } \\
\text { psychology }\end{array}$ & $\begin{array}{l}\text { Narrative process } \\
\text { analysis of the } 18 \text {-year } \\
\text { history of a professional } \\
\text { service firm }\end{array}$ & $\begin{array}{l}\text { Focus on organizational change as dialogic } \\
\text { imagination of practice } \\
\text { Three forms of imagination of practice are } \\
\text { identified as central in the development of } \\
\text { the case organization: the instantiating of } \\
\text { project experiences as identity exemplars; a } \\
\text { powerful dramatizing of trajectories of } \\
\text { practice, exemplified by use of the metaphor } \\
\text { of the "Indomitable Gauls;" and a subsequent } \\
\text { reframing instigated by discontinuous } \\
\text { changes in dominant activity sets }\end{array}$ \\
\hline $\begin{array}{l}\text { Buchanan and } \\
\text { Dawson (2007): } \\
\text { Discourse and } \\
\text { audience: } \\
\text { Organizational } \\
\text { change as multi-story } \\
\text { process }\end{array}$ & $\begin{array}{l}\text { Interpretative/ } \\
\text { poststructuralist }\end{array}$ & Organizational change & $\begin{array}{l}\text { Organizational change } \\
\text { and narrative theories }\end{array}$ & Theoretical paper & $\begin{array}{l}\text { Criticism of monological research accounts } \\
\text { that fail to accommodate plurivocal } \\
\text { narratives of organizational change } \\
\text { Organizational change viewed is a multi- } \\
\text { story process, in which theoretical accounts } \\
\text { and guides to practice are authored consistent } \\
\text { with pre-selected narrative styles }\end{array}$ \\
\hline $\begin{array}{l}\text { Fronda and Moriceau } \\
\text { (2008): I am not your } \\
\text { hero: Change } \\
\text { management and } \\
\text { culture shocks in a } \\
\text { public sector } \\
\text { corporation }\end{array}$ & Posstructuralist & Organizational change & $\begin{array}{l}\text { Narrative theories and } \\
\text { French pragmatism } \\
\text { (Boltanski \& Thévénot) }\end{array}$ & $\begin{array}{l}\text { Analysis of various } \\
\text { narratives by top and } \\
\text { middle managers and } \\
\text { organizational members } \\
\text { during a takeover }\end{array}$ & $\begin{array}{l}\text { Critical analysis of multiple worlds and } \\
\text { perspectives to make sense of change } \\
\text { Identification of various forms of narratives } \\
\text { and resistance to change }\end{array}$ \\
\hline
\end{tabular}




\begin{tabular}{|c|c|c|c|c|c|}
\hline $\begin{array}{l}\text { Sonenshein (2009): } \\
\text { Emergence of ethical } \\
\text { issues during strategic } \\
\text { change } \\
\text { implementation }\end{array}$ & Interpretative & $\begin{array}{l}\text { Organizational change } \\
\text { (implementation) }\end{array}$ & $\begin{array}{l}\text { Framing, ethics and } \\
\text { narrative theories }\end{array}$ & $\begin{array}{l}\text { Qualitative case analysis } \\
\text { of a Fortune } 500 \\
\text { company undergoing } \\
\text { strategic change }\end{array}$ & $\begin{array}{l}\text { Employees reframe the meaning of strategic } \\
\text { issues as involving ethical implications } \\
\text { because of trigger points, ambiguity, and the } \\
\text { use of an available employee welfare frame } \\
\text { These employees take the meaning of } \\
\text { strategic issues and reinterpret them as either } \\
\text { leading to harmful consequences or the } \\
\text { violation of a right }\end{array}$ \\
\hline $\begin{array}{l}\text { Sonenshein (2010): } \\
\text { We're changing - Or } \\
\text { are we? Untangling } \\
\text { the role of } \\
\text { progressive, } \\
\text { regressive, and } \\
\text { stability narratives } \\
\text { during strategic } \\
\text { change } \\
\text { implementation }\end{array}$ & Interpretative & Organizational change & $\begin{array}{l}\text { Sensemaking and } \\
\text { narrative theories }\end{array}$ & $\begin{array}{l}\text { Analysis of composite } \\
\text { narratives in a Fortune } \\
500 \text { company undergoing } \\
\text { major change }\end{array}$ & $\begin{array}{l}\text { A model of issue crafting, in which } \\
\text { individuals shape the meaning of social } \\
\text { issues by intentionally using language in } \\
\text { public that portrays those issues in ways that } \\
\text { differ from the individuals' private } \\
\text { understandings of the issues } \\
\text { Elaboration on progressive, regressive, and } \\
\text { stability narratives during strategic change } \\
\text { implementation }\end{array}$ \\
\hline $\begin{array}{l}\text { Rhodes, Pullen and } \\
\text { Clegg (2010): ‘If I } \\
\text { should fall from } \\
\text { grace..': Stories of } \\
\text { change and } \\
\text { organizational ethics. }\end{array}$ & Poststructuralist & $\begin{array}{l}\text { Organizational change } \\
\text { (ethics) }\end{array}$ & $\begin{array}{l}\text { Narrative theories } \\
\text { (especially Ricouer), } \\
\text { ethics and power }\end{array}$ & $\begin{array}{l}\text { Analysis of change } \\
\text { narratives in an } \\
\text { Australian computer } \\
\text { company }\end{array}$ & $\begin{array}{l}\text { A dominant story that seeks to legitimate } \\
\text { organizational change also serves to } \\
\text { normalize it; this diminishes the capacity for } \\
\text { organizations to scrutinize the ethics of their } \\
\text { actions } \\
\text { Narrative closure achieved by the presence of } \\
\text { a dominant narrative amongst employees } \\
\text { undergoing organizational change is } \\
\text { antithetical to the openness required for } \\
\text { ethical questioning }\end{array}$ \\
\hline
\end{tabular}




\begin{tabular}{|c|c|c|c|c|c|}
\hline $\begin{array}{l}\text { Reissner (2011): } \\
\text { Patterns of stories of } \\
\text { organisational change }\end{array}$ & Interpretative & $\begin{array}{l}\text { Patterns of stories of } \\
\text { change }\end{array}$ & Sensemaking & $\begin{array}{l}\text { Empirical analysis of } \\
\text { organizational change } \\
\text { stories in three cases in } \\
\text { three countries }\end{array}$ & $\begin{array}{l}\text { Personal accounts of change include stories } \\
\text { of “the good old days”; stories of } \\
\text { deception, taboo and silence; and stories } \\
\text { of influence } \\
\text { They stories are powerful meaning-making } \\
\text { devices and can also contest official change } \\
\text { stories. }\end{array}$ \\
\hline $\begin{array}{l}\text { Sonenshein and } \\
\text { Dholakia (2012): } \\
\text { Explaining employee } \\
\text { engagement with } \\
\text { strategic change } \\
\text { implementation: A } \\
\text { meaning-making } \\
\text { approach }\end{array}$ & Realist & $\begin{array}{l}\text { Organizational change } \\
\text { (implementation) }\end{array}$ & $\begin{array}{l}\text { Social psychological } \\
\text { and sensemaking } \\
\text { theories }\end{array}$ & $\begin{array}{l}\text { Empirical analysis of } \\
\text { qualitative and } \\
\text { quantitative data from a } \\
\text { Fortune } 500 \text { retailer } \\
\text { (narratives are used as } \\
\text { data) }\end{array}$ & $\begin{array}{l}\text { A meaning-making change adaptation model } \\
\text { (MCAM) to explain when and how } \\
\text { employees adapt to change } \\
\text { Specific types of meaning-making (strategy } \\
\text { worldview and benefits finding) can create } \\
\text { the requisite psychological resources that } \\
\text { facilitate employees engaging in change } \\
\text { implementation behaviors }\end{array}$ \\
\hline $\begin{array}{l}\text { Dailey and Browning } \\
\text { (2014): Retelling } \\
\text { stories in } \\
\text { organizations: } \\
\text { Understanding the } \\
\text { functions of narrative } \\
\text { repetition. }\end{array}$ & $\begin{array}{l}\text { Interpretative/ } \\
\text { poststructuralist }\end{array}$ & $\begin{array}{l}\text { Organizational change } \\
\text { (especially narrative } \\
\text { repetition) }\end{array}$ & $\begin{array}{l}\text { Several narrative } \\
\text { theories }\end{array}$ & Theoretical paper & $\begin{array}{l}\text { Elaboration on three dualities of sameness } \\
\text { and difference produced through narrative } \\
\text { repetition: control/resistance, } \\
\text { differentiation/integration, and } \\
\text { stability/change } \\
\text { Ambiguity of narratives: When people repeat } \\
\text { stories, some individuals may interpret a } \\
\text { narrative of stability, whereas others may } \\
\text { hear a hint of change }\end{array}$ \\
\hline
\end{tabular}


Table 3: Narratives and Identity

\begin{tabular}{|c|c|c|c|c|c|}
\hline & Approach & Focus & Theoretical basis & Methods & $\begin{array}{l}\text { Main findings / implications for stability } \\
\text { and change }\end{array}$ \\
\hline $\begin{array}{l}\text { Boje (1995): Stories } \\
\text { of the storytelling } \\
\text { organization: A } \\
\text { postmodern analysis } \\
\text { of Disney as } \\
\text { "Tamara-land" }\end{array}$ & Poststructuralist & $\begin{array}{l}\text { Organizational } \\
\text { identity }\end{array}$ & $\begin{array}{l}\text { Poststructuralist } \\
\text { theories }\end{array}$ & $\begin{array}{l}\text { Various sources of data } \\
\text { to construct and } \\
\text { deconstruct the corporate } \\
\text { history and identity } \\
\text { narratives }\end{array}$ & $\begin{array}{l}\text { Focus on the dominant versus alternative } \\
\text { versions of the corporate history and identity } \\
\text { A poststructuralist analysis of multiple } \\
\text { discourses reveals the marginalized voices } \\
\text { and the 'darker side' of the organizational } \\
\text { identity }\end{array}$ \\
\hline $\begin{array}{l}\text { Fiol (2002) } \\
\text { Capitalizing on } \\
\text { paradox: The role of } \\
\text { language in } \\
\text { transforming } \\
\text { organizational } \\
\text { identities }\end{array}$ & $\begin{array}{l}\text { Realist/ } \\
\text { interpretative }\end{array}$ & $\begin{array}{l}\text { Individual and } \\
\text { organizational identity }\end{array}$ & $\begin{array}{l}\text { Identity theories } \\
\text { (narratives implicit) }\end{array}$ & $\begin{array}{l}\text { Theoretical paper; Tech- } \\
\text { Co as an illustrative } \\
\text { example }\end{array}$ & $\begin{array}{l}\text { An identity transformation model that } \\
\text { elucidates the processes by which individual } \\
\text { and organizational levels of identity interact } \\
\text { Focus on linguistic markers that describe the } \\
\text { different stages of the process and rhetorical } \\
\text { techniques that leaders can use to guide } \\
\text { people through the process }\end{array}$ \\
\hline $\begin{array}{l}\text { Humphreys and } \\
\text { Brown (2002): } \\
\text { Narratives of } \\
\text { organizational } \\
\text { identity and } \\
\text { identification: A case } \\
\text { study of hegemony } \\
\text { and resistance }\end{array}$ & Poststructuralist & $\begin{array}{l}\text { Individual and } \\
\text { organizational identity }\end{array}$ & $\begin{array}{l}\text { Various narrative } \\
\text { theories }\end{array}$ & $\begin{array}{l}\text { Ethnographic study of } \\
\text { the working lives at } \\
\text { Westville Institute }\end{array}$ & $\begin{array}{l}\text { Identities are constructed in the personal and } \\
\text { shared narratives that people author in their } \\
\text { efforts to make sense of the world } \\
\text { Narrative identification includes dis- } \\
\text { identification, neutral identification and } \\
\text { schizo-identification }\end{array}$ \\
\hline
\end{tabular}




\begin{tabular}{|c|c|c|c|c|c|}
\hline $\begin{array}{l}\text { Chreim (2005): } \\
\text { The continuity- } \\
\text { change duality in } \\
\text { narrative texts of } \\
\text { organizational } \\
\text { identity }\end{array}$ & $\begin{array}{l}\text { Interpretative/ } \\
\text { poststructuralist }\end{array}$ & $\begin{array}{l}\text { Organizational } \\
\text { identity (continuity } \\
\text { and change) }\end{array}$ & $\begin{array}{l}\text { Several narrative } \\
\text { theories }\end{array}$ & $\begin{array}{l}\text { A narrative analysis of a } \\
10 \text {-year period at a hi- } \\
\text { tech company undergoing } \\
\text { identity transformation }\end{array}$ & $\begin{array}{l}\text { Focus on how continuity and change are } \\
\text { managed discursively in narrative texts of } \\
\text { organizational identity } \\
\text { The discursive strategies employed by } \\
\text { organizational authors to establish } \\
\text { continuity/change include selective reporting } \\
\text { of elements from the past, present and future; } \\
\text { juxtaposition of the 'modern and attractive' } \\
\text { with the 'outdated and undesirable'; use of } \\
\text { expansive labels that allow the addition and } \\
\text { subtraction of meanings attached to the } \\
\text { labels; and importation of selected themes } \\
\text { from the wider macro-discourses }\end{array}$ \\
\hline $\begin{array}{l}\text { Chreim (2007): } \\
\text { Social and temporal } \\
\text { influences on } \\
\text { interpretations of } \\
\text { organizational } \\
\text { identity and } \\
\text { acquisition } \\
\text { integration: A } \\
\text { narrative study }\end{array}$ & Interpretative & $\begin{array}{l}\text { Organizational } \\
\text { identity (in a } \\
\text { postacquisition } \\
\text { setting) }\end{array}$ & $\begin{array}{l}\text { Several narrative } \\
\text { theories }\end{array}$ & $\begin{array}{l}\text { Narratives about } \\
\text { acquisitions conducted by } \\
\text { an oil and gas company }\end{array}$ & $\begin{array}{l}\text { Organizational members' meaning } \\
\text { construction related to organizational } \\
\text { identity focused on identity enhancement or } \\
\text { threat, identity stability or ambiguity, and } \\
\text { identity continuity or discontinuity } \\
\text { Differences in interpretations were } \\
\text { influenced by the social context that included } \\
\text { elements such as encounters with other } \\
\text { groups, integration and segregation tactics } \\
\text { employed, level of communication and } \\
\text { control from higher level management, and } \\
\text { temporal context evoked by members as they } \\
\text { juxtaposed the past, present, and future } \\
\text { identity }\end{array}$ \\
\hline
\end{tabular}




\begin{tabular}{|c|c|c|c|c|c|}
\hline $\begin{array}{l}\text { Maguire and Phillips } \\
\text { (2008) } \\
\text { 'Citibankers' at } \\
\text { Citigroup: A study of } \\
\text { the loss of } \\
\text { institutional trust after } \\
\text { a merge }\end{array}$ & Interpretative & $\begin{array}{l}\text { Organizational } \\
\text { identity and trust (in a } \\
\text { postmerger context) }\end{array}$ & $\begin{array}{l}\text { Identity and narrative } \\
\text { theories }\end{array}$ & $\begin{array}{l}\text { A longitudinal analysis of } \\
\text { narrative identity- } \\
\text { building in the Citigroup } \\
\text { merger }\end{array}$ & $\begin{array}{l}\text { Focus on how issues of organizational } \\
\text { identity and identification processes } \\
\text { contributed to the loss of institutional trust } \\
\text { Institutional trust was initially undermined } \\
\text { by the ambiguity of the new organization's } \\
\text { identity and later by the absence of } \\
\text { employees' identification with the new } \\
\text { organization }\end{array}$ \\
\hline $\begin{array}{l}\text { Whittle, Mueller and } \\
\text { Mangan (2009): } \\
\text { Storytelling and } \\
\text { 'character': Victims, } \\
\text { villains and heroes in } \\
\text { a case of } \\
\text { technological change }\end{array}$ & Interpretative & $\begin{array}{l}\text { Individual identity } \\
\text { (moral accounting) }\end{array}$ & $\begin{array}{l}\text { Identity and narrative } \\
\text { theories }\end{array}$ & $\begin{array}{l}\text { An in-depth case study of } \\
\text { technological change in a } \\
\text { UK public-private } \\
\text { partnership }\end{array}$ & $\begin{array}{l}\text { Highlights the role of stories in the } \\
\text { construction, maintenance and defence of } \\
\text { actors' moral status and organizational } \\
\text { reputation } \\
\text { Stories are intimately linked to the forms of } \\
\text { 'moral accounting' that serve to deal with the } \\
\text { challenges to 'face' and social positioning } \\
\text { that accompany 'failed' organizational } \\
\text { change }\end{array}$ \\
\hline $\begin{array}{l}\text { Ybema (2010) } \\
\text { Talk of change: } \\
\text { Temporal contrasts } \\
\text { and collective } \\
\text { identities. }\end{array}$ & $\begin{array}{l}\text { Interpretative/ } \\
\text { poststructuralist }\end{array}$ & $\begin{array}{l}\text { Organizational } \\
\text { identity (temporal } \\
\text { discontinuities) }\end{array}$ & $\begin{array}{l}\text { Identity and narrative } \\
\text { theories }\end{array}$ & $\begin{array}{l}\text { Ethnographic analysis of } \\
\text { how the editors of a } \\
\text { Dutch national newspaper } \\
\text { constructed their } \\
\text { newspaper's identity }\end{array}$ & $\begin{array}{l}\text { Focus on temporal discontinuity talk, } \\
\text { discursively constructing a contrast between } \\
\text { the 'old' and the 'new,' between legacies } \\
\text { from a common past and plans for the future } \\
\text { Nostalgic and 'postalgic' narratives to } \\
\text { develop an understanding of the temporal } \\
\text { dimension of collective identity talk that does } \\
\text { not rule out, but incorporates, discontinuity } \\
\text { and change }\end{array}$ \\
\hline
\end{tabular}




\begin{tabular}{|c|c|c|c|c|c|}
\hline $\begin{array}{l}\text { Ibarra and Barbulescu } \\
\text { (2010): } \\
\text { Identity as narrative: } \\
\text { prevalence, } \\
\text { effectiveness and } \\
\text { consequences of } \\
\text { narrative identity } \\
\text { work in macro work } \\
\text { role transitions }\end{array}$ & Interpretative & Self-narratives & $\begin{array}{l}\text { Identity and narrative } \\
\text { theories }\end{array}$ & Theoretical paper & $\begin{array}{l}\text { Self-narratives help people revise and } \\
\text { reconstruct identities during work role } \\
\text { transitions }\end{array}$ \\
\hline $\begin{array}{l}\text { Gabriel, Gray and } \\
\text { Goregaokar (2010): } \\
\text { Temporary derailment } \\
\text { or the end of the line? } \\
\text { Managers coping with } \\
\text { unemployment at } 50\end{array}$ & Interpretative & $\begin{array}{l}\text { Individual narrative } \\
\text { coping }\end{array}$ & Narrative theories & $\begin{array}{l}\text { Narrative analysis of a } \\
\text { group of unemployed } \\
\text { managers and } \\
\text { professionals in their } \\
\text { fifties }\end{array}$ & $\begin{array}{l}\text { The term 'narrative coping' is proposed as a } \\
\text { way of describing each unemployed } \\
\text { professional's struggle to construct a story } \\
\text { that offers both meaning and consolation } \\
\text { Individuals expressing the most profound } \\
\text { despair were those whose stories had } \\
\text { achieved 'closure' } \\
\text { Most of those who maintained more open- } \\
\text { ended narratives were better able to contain } \\
\text { their emotions and to move on }\end{array}$ \\
\hline $\begin{array}{l}\text { Cunliffe and } \\
\text { Coupland (2011): } \\
\text { From hero to villain } \\
\text { to hero: Making } \\
\text { experience sensible } \\
\text { through embodied } \\
\text { narrative sensemaking }\end{array}$ & Poststructuralist & $\begin{array}{l}\text { Individual and } \\
\text { collective narratives } \\
\text { in embodied narrative } \\
\text { sensemaking }\end{array}$ & Narrative theories & $\begin{array}{l}\text { Narrative analysis of a } \\
\text { filmed tour of a sports } \\
\text { team }\end{array}$ & $\begin{array}{l}\text { Narratives sensemaking is embodied in } \\
\text { nature } \\
\text { It occurs in and through contested and } \\
\text { embedded narrative performances in which } \\
\text { people construct sensible and plausible } \\
\text { accounts of themselves and the collective }\end{array}$ \\
\hline $\begin{array}{l}\text { Wry, Lounsbury and } \\
\text { Glynn (2011): } \\
\text { Legitimating nascent } \\
\text { collective identities: } \\
\text { Coordinating cultural } \\
\text { entrepreneurship }\end{array}$ & $\begin{array}{l}\text { Realist/ } \\
\text { interpretative }\end{array}$ & $\begin{array}{l}\text { Organizational } \\
\text { identity (nascent) }\end{array}$ & $\begin{array}{l}\text { Institutional, cultural } \\
\text { and narrative theories }\end{array}$ & Theoretical paper & $\begin{array}{l}\text { A theoretical framework about the } \\
\text { conditions under which the collective } \\
\text { identity of a nascent entrepreneurial group is } \\
\text { more likely to be legitimated } \\
\text { Legitimacy is more likely to be achieved } \\
\text { when members articulate a clear defining }\end{array}$ \\
\hline
\end{tabular}




\begin{tabular}{|c|c|c|c|c|c|}
\hline & & & & & $\begin{array}{l}\text { collective identity story that identifies the } \\
\text { group's orienting purpose and core practices }\end{array}$ \\
\hline $\begin{array}{l}\text { Gertsen and } \\
\text { Søderberg (2011): } \\
\text { Intercultural } \\
\text { collaboration stories: } \\
\text { On narrative inquiry } \\
\text { and analysis as tools } \\
\text { for research in } \\
\text { international business }\end{array}$ & Interpretative & $\begin{array}{l}\text { Individual identity in } \\
\text { an international } \\
\text { context }\end{array}$ & $\begin{array}{l}\text { Greimas's actantial } \\
\text { model }\end{array}$ & $\begin{array}{l}\text { Analysis of interview } \\
\text { narratives of a Danish } \\
\text { expatriate manager and } \\
\text { his Chinese CEO in the } \\
\text { Shanghai subsidiary of an } \\
\text { MNE }\end{array}$ & $\begin{array}{l}\text { Demonstration of how narrative concepts } \\
\text { and models are able to elucidate intercultural } \\
\text { collaboration processes by analyzing how } \\
\text { each member of a dyad of interacting } \\
\text { managers narrates the same chain of events } \\
\text { Elaboration on differences between and } \\
\text { changes in the narrators' projects, alliances } \\
\text { and oppositions in the course of their } \\
\text { interaction }\end{array}$ \\
\hline $\begin{array}{l}\text { Vaara and Tienari } \\
\text { (2011): On the } \\
\text { narrative construction } \\
\text { of multinational } \\
\text { corporations: An } \\
\text { antenarrative analysis } \\
\text { of legitimation and } \\
\text { resistance in a cross- } \\
\text { border merger }\end{array}$ & \begin{tabular}{|l|} 
Poststructuralist \\
\end{tabular} & $\begin{array}{l}\text { Organizational and } \\
\text { national identity }\end{array}$ & $\begin{array}{l}\text { Narrative theories } \\
\text { (especially Bakhtin and } \\
\text { Boje) }\end{array}$ & $\begin{array}{l}\text { Various sources of data } \\
\text { used to reconstruct } \\
\text { understanding of } \\
\text { narratives that promoted } \\
\text { and impeded change in a } \\
\text { merging Nordic financial } \\
\text { services group }\end{array}$ & $\begin{array}{l}\text { Elaboration on three types of antenarrative } \\
\text { that provided alternatives for making sense } \\
\text { of the merger: globalist, nationalist, and } \\
\text { regionalist (Nordic) antenarratives } \\
\text { Focus on how these antenarratives were } \\
\text { mobilized in intentional organizational } \\
\text { storytelling to legitimate or resist change }\end{array}$ \\
\hline $\begin{array}{l}\text { Wright, Nyberg and } \\
\text { Grant (2012): } \\
\text { "Hippies on the third } \\
\text { floor": Climate } \\
\text { change, narrative } \\
\text { identity and the } \\
\text { micro-politics of } \\
\text { corporate } \\
\text { environmentalism }\end{array}$ & Interpretative & Individual narrative & $\begin{array}{l}\text { Identity and narrative } \\
\text { theories }\end{array}$ & $\begin{array}{l}\text { Narrative interviews of } \\
\text { sustainability specialists }\end{array}$ & $\begin{array}{l}\text { Focus on how individuals develop different } \\
\text { identities in negotiating between conflicting } \\
\text { discourses and their sense of self } \\
\text { Individuals seek to overcome conflicts } \\
\text { between identities in constructing a coherent } \\
\text { narrative of themselves and their careers }\end{array}$ \\
\hline $\begin{array}{l}\text { Schultz and Hernes } \\
\text { (2013): } \\
\text { A temporal } \\
\text { perspective on } \\
\text { organizational }\end{array}$ & Interpretative & $\begin{array}{l}\text { Organizational } \\
\text { identity }\end{array}$ & $\begin{array}{l}\text { Identity research and } \\
\text { some narrative theories }\end{array}$ & $\begin{array}{l}\text { Analysis of two occasions } \\
\text { of identity reconstruction } \\
\text { in the LEGO group }\end{array}$ & $\begin{array}{l}\text { A longer time perspective in the use of } \\
\text { memory enabled a longer time perspective in } \\
\text { formulating claims for future identity } \\
\text { A broader scope of articulated identity }\end{array}$ \\
\hline
\end{tabular}


Narratives as Sources of Stability and Change in Organizations

\begin{tabular}{|l|l|l|l|l|l|}
\hline identity & & & $\begin{array}{l}\text { claims for the future was related to the } \\
\text { combination of a broader range of memory } \\
\text { forms }\end{array}$ \\
$\begin{array}{l}\text { The depth of claims for future identity was } \\
\text { related to the way in which memory forms } \\
\text { were combined }\end{array}$ & $\begin{array}{l}\text { Identification of four storylines that reflect } \\
\text { distinct forms of courage and one storyline } \\
\text { that reflects a lack of courage }\end{array}$ \\
$\begin{array}{l}\text { Koerner (2014): } \\
\text { courage as identity } \\
\text { workplace courage. }\end{array}$ & Interpretative & $\begin{array}{l}\text { Individual identities } \\
\text { and workplace } \\
\text { courage }\end{array}$ & $\begin{array}{l}\text { Identity and narrative } \\
\text { theories }\end{array}$ & $\begin{array}{l}\text { Narratives about } \\
\text { courageous acts } \\
\text { performed or observed } \\
\text { by individuals in a } \\
\text { variety contexts }\end{array}$ & $\begin{array}{l}\text { Identity tensions precipitate courageous acts, } \\
\text { and courage-based identity work is used to } \\
\text { reconcile the tensions }\end{array}$ \\
\hline
\end{tabular}


Table 4: Narratives and Strategy

\begin{tabular}{|c|c|c|c|c|c|}
\hline & Approach & Focus & Theoretical basis & Methods & $\begin{array}{l}\text { Main findings / implications for stability } \\
\text { and change }\end{array}$ \\
\hline $\begin{array}{l}\text { Barry \& Elmes } \\
\text { (1997): Strategy } \\
\text { retold: Toward a } \\
\text { narrative view of } \\
\text { strategic discourse }\end{array}$ & Interpretative & Strategy-making & $\begin{array}{l}\text { Several narrative } \\
\text { theories, especially } \\
\text { Shklovsky }\end{array}$ & Theoretical paper & $\begin{array}{l}\text { A narrative conceptualization of strategic } \\
\text { management as ‘fiction' } \\
\text { Focus on the challenges that strategists face } \\
\text { in making strategic discourse both credible } \\
\text { and novel } \\
\text { Elaboration of strategy narrative forms such } \\
\text { as epic, technofuturist and purist }\end{array}$ \\
\hline $\begin{array}{l}\text { Dunford \& Jones } \\
\text { (2000): Narrative in } \\
\text { strategic change }\end{array}$ & Interpretative & Strategic change & $\begin{array}{l}\text { Sensemaking and } \\
\text { sensegiving }\end{array}$ & $\begin{array}{l}\text { Analysis of senior } \\
\text { managers' strategic } \\
\text { change narratives (in } \\
\text { three tech companies) }\end{array}$ & $\begin{array}{l}\text { Sensegiving in strategic change involves } \\
\text { narratives } \\
\text { Elaboration of various forms of narratives } \\
\text { and reactions to them }\end{array}$ \\
\hline $\begin{array}{l}\text { Brown \& Humphreys } \\
\text { (2003): Epic and } \\
\text { tragic tales: Making } \\
\text { sense of change }\end{array}$ & Interpretative & Strategic change & $\begin{array}{l}\text { Several narrative } \\
\text { theories }\end{array}$ & $\begin{array}{l}\text { Analysis of senior } \\
\text { managers' and } \\
\text { organizational members' } \\
\text { narratives of strategic } \\
\text { change (in a UK college) }\end{array}$ & $\begin{array}{l}\text { Divergence in narratives of strategic change: } \\
\text { senior managers told epic stories while the } \\
\text { subordinates' narratives were tragic in } \\
\text { orientation } \\
\text { Narratives are both enablers and constraints } \\
\text { for strategic change }\end{array}$ \\
\hline $\begin{array}{l}\text { Fenton \& Langley } \\
\text { (2011): Strategy as } \\
\text { practice and the } \\
\text { narrative turn }\end{array}$ & Interpretative & Strategic practices & $\begin{array}{l}\text { Communicative } \\
\text { construction of } \\
\text { organizations (CCO) }\end{array}$ & Theoretical paper & $\begin{array}{l}\text { Multiple levels and forms of narrative are } \\
\text { inherent to strategic practices } \\
\text { Narrative is seen as a way of giving meaning } \\
\text { to the practice that emerges from } \\
\text { sensemaking activities, of constituting an } \\
\text { overall sense of direction or purpose, of } \\
\text { refocusing organizational identity, and of }\end{array}$ \\
\hline
\end{tabular}




\begin{tabular}{|c|c|c|c|c|c|}
\hline & & & & & $\begin{array}{l}\text { enabling and constraining the ongoing } \\
\text { activities of actors }\end{array}$ \\
\hline $\begin{array}{l}\text { Kaplan \& Orlikowski } \\
\text { (2013): } \\
\text { Temporal work in } \\
\text { strategy making }\end{array}$ & Interpretative & \begin{tabular}{|l|} 
Strategy-making \\
\end{tabular} & $\begin{array}{l}\text { Temporality and } \\
\text { practice theories } \\
\text { (narrative theories } \\
\text { implicit) }\end{array}$ & $\begin{array}{l}\text { Field study of strategy } \\
\text { making in an organization } \\
\text { facing an industry crisis }\end{array}$ & $\begin{array}{l}\text { Organizational participants struggle with } \\
\text { competing interpretations of what might } \\
\text { emerge in the future, what was currently at } \\
\text { stake, and even what had happened in the } \\
\text { past } \\
\text { A model of temporal work in strategy } \\
\text { making that articulates how actors resolve } \\
\text { differences to construct a strategic account } \\
\text { that enables strategic choice and action } \\
\text { Settling on a particular account requires it to } \\
\text { be coherent, plausible, and acceptable }\end{array}$ \\
\hline $\begin{array}{l}\text { Küpers, Mantere \& } \\
\text { Statler (2013): } \\
\text { Strategy as } \\
\text { storytelling: A } \\
\text { phenomenological } \\
\text { collaboration }\end{array}$ & Interpretative & Strategy-making & $\begin{array}{l}\text { Various } \\
\text { phenomenological and } \\
\text { narrative theories }\end{array}$ & $\begin{array}{l}\text { Phenomenological } \\
\text { inquiry of storytelling } \\
\text { practices in corporate } \\
\text { strategy-making } \\
\text { processes as experienced } \\
\text { by nonsenior } \\
\text { organizational members }\end{array}$ & $\begin{array}{l}\text { Identification of three embodied narrative } \\
\text { practices enacted in a workshop event: } \\
\text { discursive struggles over "hot" words, the } \\
\text { de-sacralization of strategy, and recurring } \\
\text { rituals of self-sacrifice. }\end{array}$ \\
\hline $\begin{array}{l}\text { Vaara \& Pedersen } \\
\text { (2014): Strategy and } \\
\text { chronotopes: a } \\
\text { Bakhtinian } \\
\text { perspective on the } \\
\text { construction of } \\
\text { strategy narratives }\end{array}$ & Poststructuralist & Strategy-making & $\begin{array}{l}\text { Bakhtinian notions of } \\
\text { narratives and } \\
\text { chronotopes }\end{array}$ & Theoretical paper & $\begin{array}{l}\text { Processes through which understandings of } \\
\text { time and space are constructed in strategy } \\
\text { narratives } \\
\text { Strategy narratives involve various genres } \\
\text { with 'chronotopes' characteristic to each } \\
\text { genre combining specific senses of time and } \\
\text { place; these are enabling and constraining } \\
\text { resources for strategy-making }\end{array}$ \\
\hline
\end{tabular}


Table 5: Narratives and Entrepreneurship

\begin{tabular}{|c|c|c|c|c|c|}
\hline & Approach & Focus & Theoretical basis & Methods & $\begin{array}{l}\text { Main findings / implications for stability } \\
\text { and change }\end{array}$ \\
\hline $\begin{array}{l}\text { Lounsbury \& Glynn } \\
\text { (2001): Cultural } \\
\text { entrepreneurship: } \\
\text { stories, legitimacy, } \\
\text { and the acquisition of } \\
\text { resources }\end{array}$ & Realist & $\begin{array}{l}\text { Entrepreneurial } \\
\text { identity and } \\
\text { legitimacy }\end{array}$ & $\begin{array}{l}\text { Cultural theories and } \\
\text { storytelling }\end{array}$ & Theoretical paper & $\begin{array}{l}\text { A framework that explains how } \\
\text { entrepreneurial stories facilitate the crafting } \\
\text { of a new venture identity, establishing } \\
\text { legitimacy and wealth creation } \\
\text { Stories help create competitive advantage } \\
\text { for entrepreneurs by two key forms of } \\
\text { entrepreneurial capital: firm-specific } \\
\text { resource capital and industry-level } \\
\text { institutional capital }\end{array}$ \\
\hline $\begin{array}{l}\text { O’Connor (2002): } \\
\text { Storied business: } \\
\text { Typology, } \\
\text { intertextuality, and } \\
\text { traffic in } \\
\text { entrepreneurial } \\
\text { narrative }\end{array}$ & Interpretative & $\begin{array}{l}\text { Entrepreneurial } \\
\text { identity and } \\
\text { legitimacy }\end{array}$ & $\begin{array}{l}\text { Several narrative } \\
\text { theories }\end{array}$ & Ethnographic study & $\begin{array}{l}\text { Identification of six basic narrative types: } \\
\text { founding, visionary, marketing, strategy, } \\
\text { historical, and conventional } \\
\text { These stories enable founders to justify the } \\
\text { existence of the company, convince others to } \\
\text { devote funds and other key resources to the } \\
\text { company, and make key decisions in the } \\
\text { short and intermediate term }\end{array}$ \\
\hline $\begin{array}{l}\text { Nicholson \& } \\
\text { Anderson (2005): } \\
\text { News and nuances of } \\
\text { the entrepreneurial } \\
\text { myth and metaphor: } \\
\text { Linguistic games in } \\
\text { entrepreneurial sense- } \\
\text { making and sense- } \\
\text { giving }\end{array}$ & $\begin{array}{l}\text { Interpretative/ } \\
\text { poststructural }\end{array}$ & $\begin{array}{l}\text { Entrepreneurial } \\
\text { identity (as portrayed } \\
\text { in the media with } \\
\text { metaphors) }\end{array}$ & $\begin{array}{l}\text { Sensemaking and } \\
\text { metaphors }\end{array}$ & $\begin{array}{l}\text { Content analysis of media } \\
\text { texts }\end{array}$ & $\begin{array}{l}\text { Myth and metaphor in newspapers are key } \\
\text { parts of the social construction of } \\
\text { entrepreneurial culture } \\
\text { Images of male entrepreneurs as dynamic } \\
\text { wolfish charmers, supernatural gurus, } \\
\text { successful skyrockets or community saviors } \\
\text { and corrupters }\end{array}$ \\
\hline
\end{tabular}




\begin{tabular}{|c|c|c|c|c|c|}
\hline $\begin{array}{l}\text { Martens, Jennings \& } \\
\text { Jennings (2007): } \\
\text { Entrepreneurial } \\
\text { strategy narratives } \\
\text { and resource } \\
\text { acquisitions in ipos }\end{array}$ & Realist & $\begin{array}{l}\text { Entrepreneurial } \\
\text { identity and resource } \\
\text { acquisition }\end{array}$ & $\begin{array}{l}\text { Narrative theories } \\
\text { linked with resource } \\
\text { acquisition research }\end{array}$ & $\begin{array}{l}\text { Qualitative analysis of } \\
\text { initial public offering } \\
\text { prospectuses in three } \\
\text { high-tech industries } \\
\text { combined with statistical } \\
\text { analysis of performance }\end{array}$ & $\begin{array}{l}\text { Effective storytelling can significantly } \\
\text { facilitate resource acquisition } \\
\text { The narrative devices used include } \\
\text { persuasive appeals, elaboration, and } \\
\text { familiarity and unfamiliarity }\end{array}$ \\
\hline $\begin{array}{l}\text { Zilber (2007): Stories } \\
\text { and the discursive } \\
\text { dynamics of } \\
\text { institutional } \\
\text { entrepreneurship: The } \\
\text { case of Israeli high- } \\
\text { tech after the bubble }\end{array}$ & Interpretative & $\begin{array}{l}\text { Institutional } \\
\text { entrepreneurship and } \\
\text { entrepreneurial failure }\end{array}$ & $\begin{array}{l}\text { Discursive and } \\
\text { narrative theories }\end{array}$ & $\begin{array}{l}\text { Analysis of stories told in } \\
\text { a fieldwide high-tech } \\
\text { conference in Israel after } \\
\text { the dot-com crash of } \\
2000\end{array}$ & $\begin{array}{l}\text { Actors were engaged in constructing a } \\
\text { shared story of the crisis that reflected and } \\
\text { further strengthened the established } \\
\text { institutional order } \\
\text { Concurrently, the same actors were also } \\
\text { each telling a counter-story of indictment, } \\
\text { blaming other groups for the crisis and } \\
\text { calling for changes in the institutional order } \\
\text { Focus on the efforts of both collaboration in } \\
\text { maintaining the institutional order and } \\
\text { contestation that could potentially disrupt it }\end{array}$ \\
\hline $\begin{array}{l}\text { Down \& Warren } \\
\text { (2008): Constructing } \\
\text { narratives of } \\
\text { enterprise: Clichés } \\
\text { and entrepreneurial } \\
\text { self-identity }\end{array}$ & Poststructuralist & $\begin{array}{l}\text { Entrepreneurial } \\
\text { identity }\end{array}$ & $\begin{array}{l}\text { Various narrative } \\
\text { theories }\end{array}$ & $\begin{array}{l}\text { Ethnographic study of a } \\
\text { small UK industrial firm }\end{array}$ & $\begin{array}{l}\text { Clichés used by aspirant entrepreneurs are } \\
\text { significant elements in creating } \\
\text { entrepreneurial self-identity } \\
\text { Analysis of these clichés helps understand } \\
\text { the everyday and ordinary elements of } \\
\text { identity construction as well as to critically } \\
\text { evaluate them }\end{array}$ \\
\hline
\end{tabular}




\begin{tabular}{|c|c|c|c|c|c|}
\hline $\begin{array}{l}\text { Essers \& Benschop } \\
\text { (2008): Enterprising } \\
\text { identities: } \\
\text { entrepreneurs of } \\
\text { Moroccan or Turkish } \\
\text { origin in the } \\
\text { Netherlands }\end{array}$ & Poststructuralist & $\begin{array}{l}\text { Cultural bases of } \\
\text { entrepreneurship }\end{array}$ & $\begin{array}{l}\text { Narratives analysis and } \\
\text { feminism }\end{array}$ & $\begin{array}{l}\text { Narrative analysis of life } \\
\text { stories of female } \\
\text { entrepreneurs of } \\
\text { Moroccan or Turkish } \\
\text { origin in the Netherlands }\end{array}$ & $\begin{array}{l}\text { Identity work varies in the degree of } \\
\text { conformity: to follow conventional images } \\
\text { of femininity, to denounce femininity and/or } \\
\text { ethnicity, or to resist the masculine } \\
\text { connotations of entrepreneurship } \\
\text { Criticism of the dominant image of white } \\
\text { male entrepreneurs }\end{array}$ \\
\hline $\begin{array}{l}\text { Navis \& Glynn } \\
\text { (2011): Legitimate } \\
\text { distinctiveness and } \\
\text { the entrepreneurial } \\
\text { identity: Influence on } \\
\text { investor judgments of } \\
\text { new venture } \\
\text { plausibility }\end{array}$ & Realist & $\begin{array}{l}\text { Entrepreneurial } \\
\text { identity }\end{array}$ & $\begin{array}{l}\text { Institutional and } \\
\text { cultural theories }\end{array}$ & Theoretical paper & $\begin{array}{l}\text { Entrepreneurial identities are judged } \\
\text { favorably when they are legitimately } \\
\text { distinctive } \\
\text { Such judgments are influenced by market } \\
\text { context and mediated by identity narratives } \\
\text { that provide institutional primes and } \\
\text { equivocal cues for investor sensemaking }\end{array}$ \\
\hline $\begin{array}{l}\text { Mantere et al. (2013): } \\
\text { Narrative attributions } \\
\text { of entrepreneurial } \\
\text { failure }\end{array}$ & Interpretative & $\begin{array}{l}\text { Entrepreneurial } \\
\text { failure }\end{array}$ & $\begin{array}{l}\text { Narrative and } \\
\text { sociopsychological } \\
\text { theories }\end{array}$ & \begin{tabular}{|l|} 
Narratives of \\
stakeholders as they \\
explain failure in three \\
different IT startups
\end{tabular} & $\begin{array}{l}\text { Identification of narrative attributions, i.e., } \\
\text { alternative accounts of failure that actors } \\
\text { draw on to process the failure and their role } \\
\text { in it } \\
\text { These include "Catharsis" (personal } \\
\text { responsibility), "Hubris” (venture-wide } \\
\text { responsibility), "Zeitgeist” (industry-wide } \\
\text { responsibility), "Betrayal” (responsible agent } \\
\text { inside the venture), "Nemesis” (responsible } \\
\text { external agent), "Mechanistic" } \\
\text { (uncontrollable non-human element within } \\
\text { the venture), and "Fate” (uncontrollable non- } \\
\text { human element external to the venture }\end{array}$ \\
\hline $\begin{array}{l}\text { Garud \& Giuliani } \\
\text { (2013): A narrative } \\
\text { perspective on } \\
\text { entrepreneurial }\end{array}$ & Interpretative & $\begin{array}{l}\text { Entrepreneurial } \\
\text { opportunity }\end{array}$ & $\begin{array}{l}\text { Narrative theories, } \\
\text { Actor Network Theory }\end{array}$ & \begin{tabular}{|l|} 
Theoretical paper \\
\end{tabular} & $\begin{array}{l}\text { The narrative perspective on entrepreneurial } \\
\text { agency and entrepreneurial opportunities } \\
\text { suggests there is an entrepreneurial journey }\end{array}$ \\
\hline
\end{tabular}


Narratives as Sources of Stability and Change in Organizations

\begin{tabular}{|c|c|c|c|c|c|}
\hline opportunities. & & & & & $\begin{array}{l}\text { Discovery and creation are dynamic forces } \\
\text { and meaning making results from an } \\
\text { interaction of relational space and durational } \\
\text { time when the past, present, and future are } \\
\text { intertwined }\end{array}$ \\
\hline $\begin{array}{l}\text { Garud, Schildt \& Lant } \\
\text { (2014): } \\
\text { Entrepreneurial } \\
\text { storytelling, future } \\
\text { expectations, and the } \\
\text { paradox of legitimacy }\end{array}$ & $\begin{array}{l}\text { Realist/ } \\
\text { interpretative }\end{array}$ & $\begin{array}{l}\text { Entrepreneurial } \\
\text { legitimacy }\end{array}$ & $\begin{array}{l}\text { Institutional, cultural } \\
\text { and narrative theories }\end{array}$ & Theoretical paper & $\begin{array}{l}\text { A paradox in entrepreneurial storytelling: } \\
\text { the very expectations that are set through } \\
\text { projective stories to gain venture legitimacy } \\
\text { can also serve as the source of future } \\
\text { disappointments } \\
\text { Analysis of the constraints and possibilities } \\
\text { of maintaining or regaining legitimacy } \\
\text { through revised storytelling }\end{array}$ \\
\hline
\end{tabular}


Table 5: Narratives and Personal Growth

\begin{tabular}{|c|c|c|c|c|c|}
\hline & Approach & Focus & Theoretical basis & Methods & $\begin{array}{l}\text { Main findings / implications for stability } \\
\text { and change }\end{array}$ \\
\hline $\begin{array}{l}\text { Roberts, Dutton, } \\
\text { Spreitzer, Heaphy \& } \\
\text { Quinn (2005) }\end{array}$ & Interpretive & $\begin{array}{l}\text { Individual growing as } \\
\text { form of positive self- } \\
\text { change }\end{array}$ & $\begin{array}{l}\text { Career and personal } \\
\text { change; personal and } \\
\text { contextual resources } \\
\text { that shape sensemaking }\end{array}$ & Theoretical paper & $\begin{array}{l}\text { A framework that explains how } \\
\text { entrepreneurial stories facilitate the crafting } \\
\text { of a new venture identity, establishing } \\
\text { legitimacy and wealth creation } \\
\text { Stories help create competitive advantage } \\
\text { for entrepreneurs by two key forms of } \\
\text { entrepreneurial capital: firm-specific } \\
\text { resource capital and industry-level } \\
\text { institutional capital }\end{array}$ \\
\hline Maitlis (2009) & Interpretive & $\begin{array}{l}\text { Personal change after } \\
\text { traumatic event }\end{array}$ & $\begin{array}{l}\text { Integration of post- } \\
\text { traumatic growth } \\
\text { research with } \\
\text { narratives. }\end{array}$ & $\begin{array}{l}\text { Interviews with } \\
\text { musicians who can no } \\
\text { longer play after life- } \\
\text { changing injury }\end{array}$ & $\begin{array}{l}\text { Identification of six basic narrative types: } \\
\text { founding, visionary, marketing, strategy, } \\
\text { historical, and conventional } \\
\text { These stories enable founders to justify the } \\
\text { existence of the company, convince others to } \\
\text { devote funds and other key resources to the } \\
\text { company, and make key decisions in the } \\
\text { short and intermediate term }\end{array}$ \\
\hline $\begin{array}{l}\text { Shipp \& Jansen } \\
\text { (2011) }\end{array}$ & Realist & $\begin{array}{l}\text { Person-environment } \\
\text { fit research }\end{array}$ & $\begin{array}{l}\text { Introduce narratives as } \\
\text { way of accounting for } \\
\text { constant change and } \\
\text { temporality in person- } \\
\text { organizational fit } \\
\text { research. }\end{array}$ & Theoretical paper & $\begin{array}{l}\text { Myth and metaphor in newspapers are key } \\
\text { parts of the social construction of } \\
\text { entrepreneurial culture } \\
\text { Images of male entrepreneurs as dynamic } \\
\text { wolfish charmers, supernatural gurus, } \\
\text { successful skyrockets or community saviors } \\
\text { and corrupters }\end{array}$ \\
\hline
\end{tabular}


Narratives as Sources of Stability and Change in Organizations

\begin{tabular}{|c|c|c|c|c|c|}
\hline $\begin{array}{l}\text { Lawrence \& Maitlis } \\
\text { (2012) }\end{array}$ & Interpretive & $\begin{array}{l}\text { Relational narratives } \\
\text { enact care }\end{array}$ & $\begin{array}{l}\text { Feminist theories (ethic } \\
\text { of care) }\end{array}$ & Theoretical paper & $\begin{array}{l}\text { Effective storytelling can significantly } \\
\text { facilitate resource acquisition } \\
\text { The narrative devices used include } \\
\text { persuasive appeals, elaboration, and } \\
\text { familiarity and unfamiliarity }\end{array}$ \\
\hline $\begin{array}{l}\text { Sonenshein, Dutton, } \\
\text { Grant, Spreitzer \& } \\
\text { Sutcliffe (2013) }\end{array}$ & Interpretive & $\begin{array}{l}\text { Individual growing as } \\
\text { form of positive self- } \\
\text { change }\end{array}$ & $\begin{array}{l}\text { Personal and contextual } \\
\text { resources that shape } \\
\text { sensemaking }\end{array}$ & $\begin{array}{l}\text { Qualitative analysis of } 55 \\
\text { employees across three } \\
\text { organizations } \\
\text { (manufacturing, financial } \\
\text { services, and non-profit) } \\
\text { using employees' } \\
\text { personal stories of } \\
\text { growing. }\end{array}$ & $\begin{array}{l}\text { Actors were engaged in constructing a } \\
\text { shared story of the crisis that reflected and } \\
\text { further strengthened the established } \\
\text { institutional order } \\
\text { Concurrently, the same actors were also } \\
\text { each telling a counter-story of indictment, } \\
\text { blaming other groups for the crisis and } \\
\text { calling for changes in the institutional order } \\
\text { Focus on the efforts of both collaboration in } \\
\text { maintaining the institutional order and } \\
\text { contestation that could potentially disrupt it }\end{array}$ \\
\hline
\end{tabular}


Narratives as Sources of Stability and Change in Organizations 